\title{
Disposal of Fluidized-Bed Combustion Ash In An Underground Mine to Control Acid Mine Drainage and Subsidence
}

\author{
Quarterly Report \\ December 1994 - February 1995
}

March 1995

Work Performed Under Contract No.: DE-FC21-94MC29244

For

U.S. Department of Energy

Office of Fossil Energy

Morgantown Energy Technology Center

Morgantown, West Virginia

By

West Virginia University Research Corporation

Morgantown, West Virginia 


\section{DISCLAIMER}

This report was prepared as an account of work sponsored by an agency of the United States Government. Neither the United States Government nor any agency thereof, nor any of their employees, makes any warranty, express or implied, or assumes any legal liability or responsibility for the accuracy, completeness, or usefulness of any information, apparatus, product, or process disclosed, or represents that its use would not infringe privately owned rights. Reference herein to any specific commercial product, process, or service by trade name, trademark, manufacturer, or otherwise does not necessarily constitute or imply its endorsement, recommendation, or favoring by the United States Government or any agency thereof. The views and opinions of authors expressed herein do not necessarily state or reflect those of the United States Government or any agency thereof.

This report has been reproduced directly from the best available copy.

Available to DOE and DOE contractors from the Office of Scientific and Technical Information, 175 Oak Ridge Turnpike, Oak Ridge, TN 37831; prices available at (615) 576-8401.

Available to the public from the National Technical Information Service, U.S. Department of Commerce, 5285 Port Royal Road, Springfield, VA 22161; phone orders accepted at (703) 487-4650. 
翼

z영

정원

号客最

옹요

ํㅜㄹ

国

곡

O

家家

政

등뭉

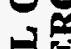

ชูํㅡㄹ

娄娄

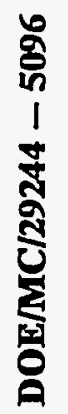




\title{
Disposal of Fluidized-Bed Combustion Ash In An Underground Mine to Control Acid Mine Drainage and Subsidence
}

\author{
Quarterly Report \\ December 1994 - February 1995
}

Work Performed Under Contract No.: DE-FC21-94MC29244

\author{
For \\ U.S. Department of Energy \\ Office of Fossil Energy \\ Morgantown Energy Technology Center \\ P.O. Box 880 \\ Morgantown, West Virginia 26507-0880
}

By

West Virginia University Research Corporation

P.O. Box 6064

West Virginia University

Morgantown, West Virginia 26506-6064

March 1995 


\section{Progress Report \\ for the Quarter of}

\section{December 1, 1994 to February 28, 1995}

\section{Project - ETD05 "Disposal of Fluidized Bed Combustion Ash in an Underground Mine to Control Acid Mine Drainage and Subsidence" \\ DE-FC21-94MC29244}

During Phase I (first 18 months) the project is segregated into four areas of reporting: A) Grout Formulation, B) Grout Characterization, C) Water Quality Monitoring, D) Subsidence Control \& Contaminant Transport. The first component involves formulating a grout mixture with appropriate flowability and strength (flow and strength requirements will be set by other components) to be used in filling complex mine voids. The Grout Characterization component will determine the flowability characteristics of the formulated grout and model the flow of the grout filling the mine void. The Water Quality component involves background monitoring of water quality and precipitation at the Phase III (Longridge) mine site. The last component involves evaluating the strength requirements and the migration of contaminants through the candidate grouts.

This report separately discusses progress on all components of the program in order of project subtask. The subtasks are arranged according to the Network Diagram on the following pages. Progress for each subtask can be seen in the Gantt Chart following the Network Diagram.

During this reporting period the research team observed the installation of a coal ash grout into and underground mine void. The installation occurred at the future site of the West Virginia High Tech Consortium in Marion County, West Virginia. Originally the grout to be used was made up of Fluidized Bed Combustion ash and water, but problems arose and a mixture of $10 \%$ Portland cement and $90 \%$ Class $\mathrm{F}$ ash from the Harrison Power Station were used. It should be noted that the Grant Town Power Station which produced the FBC ash operates with a similar Alstrom Boiler unit that is located in the MEA Plant in Morgantown.

Courtney Black, the Project Manager, observed the initial trials with the FBC grout and reported that no care was taken in the mixing of the grout. Approximately 300 gallons of water was transported in a mixer truck to the Grant Town Power Station. Here five tons of ash was added to the truck. The ash is approximately 300 degrees Fahrenheit and caused a significant amount of water to "flash off." After loading the truck then traveled 45 minutes to the test site. The driver did not start mixing the grout until he reached the site. When the truck arrived at the test site the grout consisted of small clumps and moist particles.

By initial calculations the water to solids ratio would have been near $25 \%$ (percentage of dry weight), a ratio slightly less than WVU researchers have determined to be optimum. The personnel performing this field test also let the grout mixture sit in the truck approximately six 
hours before unloading. This caused large clumps to form as the grout tried to harden.

The following week the personnel at the field site switched the grout components to Portland cement and Class F ash. The entire WVU research team observed this operation. This material behaved like a high slump concrete. The engineer in charge of the field operation noted that the FBC material was more complicated to work with than was originally thought. $\mathrm{He}$ also noted that he would watch for WVU's results to be published in journals and conferences in the area. 


\section{Gantt Chart}

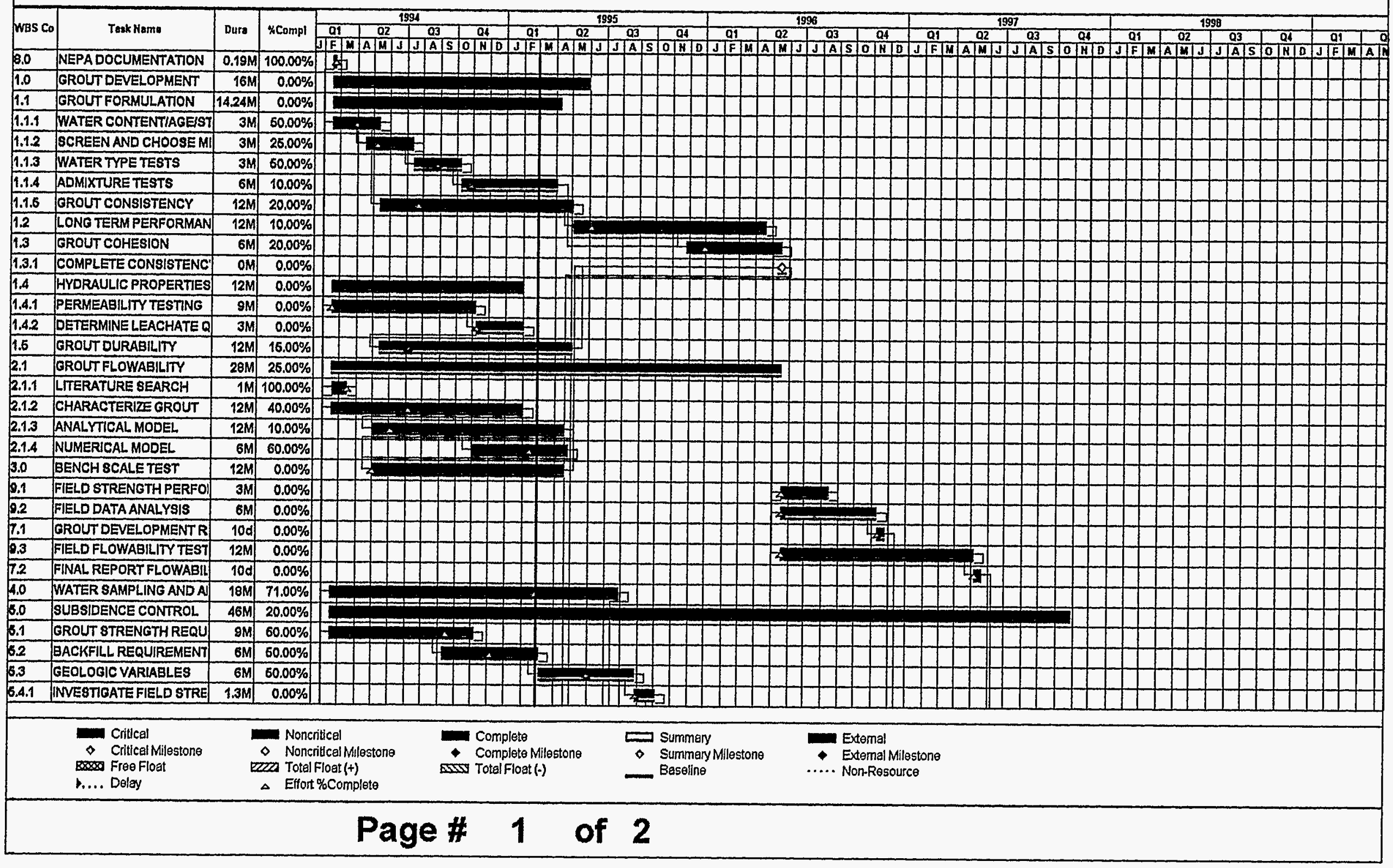




\section{Gantt Chart}

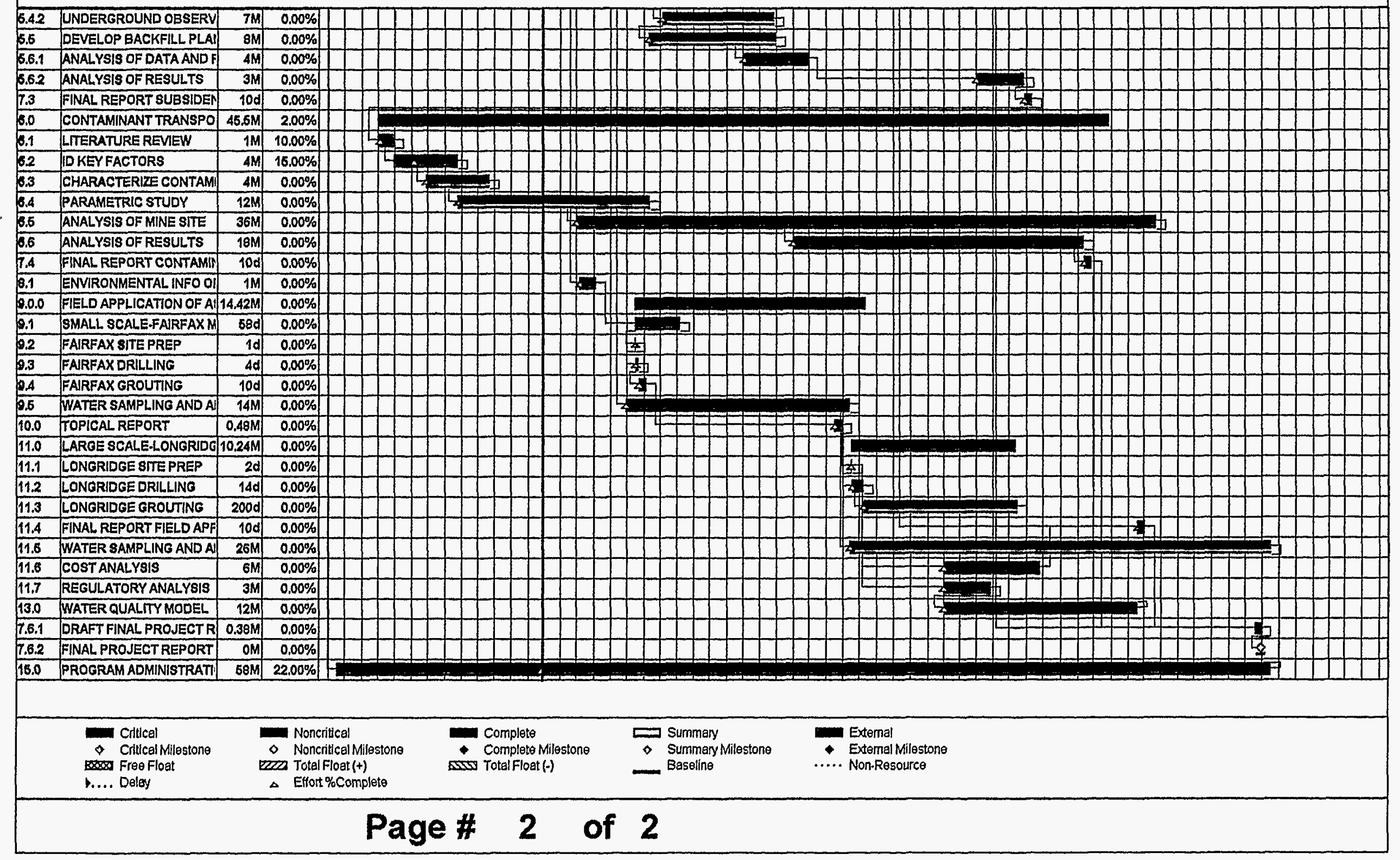




\section{Network Diagram}

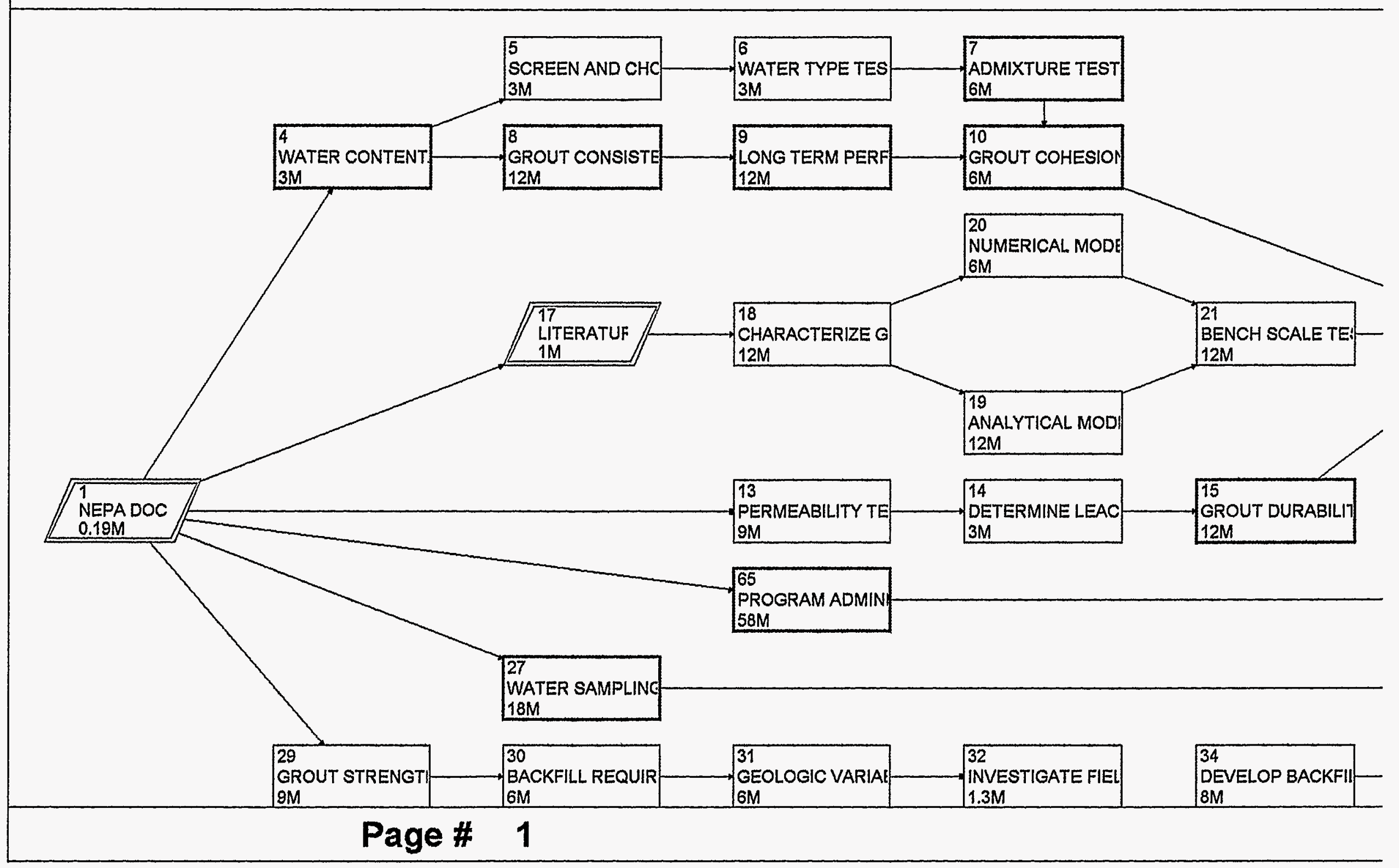




\section{Network Diagram}

$a$

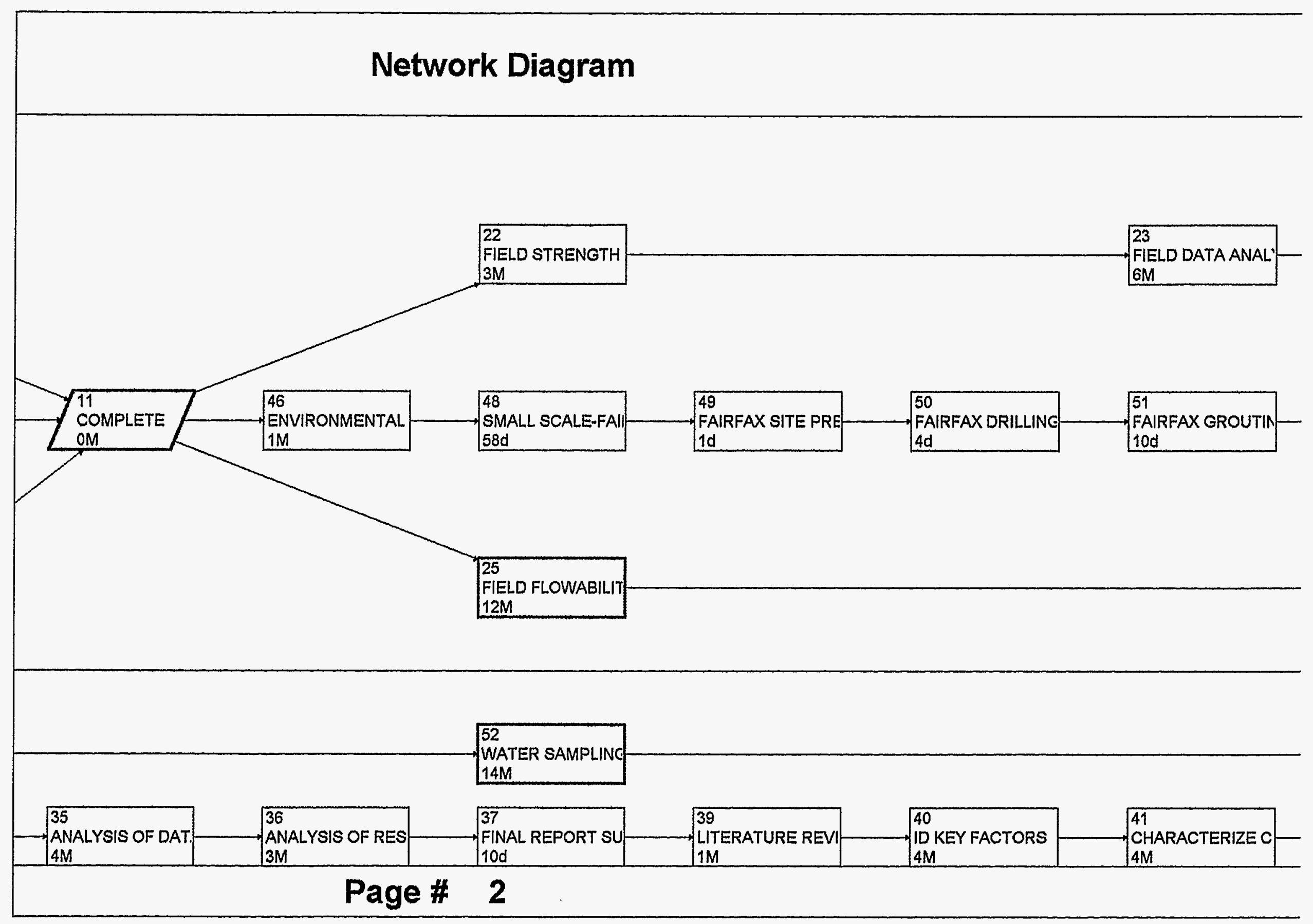




\section{A. Grout Formulation}

\subsection{Task Description:}

\section{Grout Development}

The purpose of this task is to develop a grout formulation that will be capable of filling complex mine voids while displaying strength great enough to prevent subsidence. This task involves the physical mixing and testing of grouts while keeping in close communication with Dr. Siriwardane's and Dr. Gray's research teams. Dr. Siriwardane's team will evaluate the strength requirements needed for subsidence control while Dr. Gray's team will be responsible for grout rheology or flowability.

\subsection{Summary of Accomplishments and Significant Events}

2.1 Continued assessments of changes in grout strengths with time. As shown in figure 1, compressive strengths at ages 90 and 180 days are now available for mixes with selected water contents. As noted in previous reports, grout strength is inversely related to water content at all ages. In addition, it also appears that for the water contents considered, the rate of strength gain decreased markedly between 30 and 60 days after modeling of the test specimens. An encouraging note is that grout strengths in excess of 1000 psi after 30 days curing can be readily attained with relatively high water contents for a grout whose solids content is half fine and half coarse ash. It should be noted that the 50:50 fine:coarse blend was selected for testing because that blend represents, on average, the approximate proportions of the material produced at the Morgantown Energy Associates Beechurst Power Station.

2.2 Assessed flexural strength of grout mixes as a function of age. Shown in Figure 2 are the results of flexure tests performed on beam samples of two grout mixes. the first set of tests were performed on specimens made with conventional 50:50 solid blend at a water content of $31 \%$ of the total weight of the specimen. The second series of tests were performed on specimens made of fine material only. These specimens required a water content of $41.5 \%$ to attain the same consistency (10 to 12 inch slump) as the specimens with the 50:50 blend. All specimens tend to exhibit relatively low flexural strengths at all ages. In addition, flexural strength tended to increase with age. Both results were anticipated. Also illustrated in the plot is the fact that specimens made from fine material only tend to be stronger than similar specimens made from the blended ashes. This trend was also apparent when specimens of each type were tested in compression.

2.3 Assessed changes in consistency (slump loss) with time for grouts made of fine material only. Of particular interest in these results are specimens made from two lots of material obtained at different times. Approximately 45 to 60 days was the time interval between when the lots were obtained form the MEA plant. It should be noted that the two materials were dissimilar in terms of the water content required to produce the standard 
10 to 12 inch slump and in terms of the rates art which slump was lost. These results underscore the notion that the MEA plant does not produce ash which is consistent in characteristics. Perhaps a simple test procedure, such as amount of material passing a critical sieve, can be devised to alert users of the ash that changes have occurred in the material.

2.4 Initiated tests of grouts that contain an admixture, Portland cement. The intent here is to assess the feasibility of adding substances in small amounts to grouts to reduce the tendency of grouts to segregate. Preliminary results of flow tests seem to indicate that difficulty will be encountered with segregation of grouts containing coarse ash; Portland cement particles may lessen that tendency.

2.5 Met with MEA and Anker Energy personnel to discuss strategies for handling ash materials at both the plant site and the grout mixing/installation site. ME personnel indicated that it might be possible to reduce the variability of the ash blend by utilizing holding facilities at the plant to absorb the surges in particle collection that seem to occur on a random basis. This option is under consideration. Anker Energy personnel indicated that it may be possible to discharge all ash at a central location near the mine site and utilize conventional construction equipment to blend the ashes to achieve a reasonably uniform material. Problems exist with this approach; this option, too, is under consideration.

2.6 Attended regular staff meetings.

2.7 Continued literature review.

\subsection{To-Date Accomplishments:}

As noted above.

\subsection{Technical Progress Report:}

Results of laboratory testing of grout mixtures appear in Figures $1-3$ attached to this report. Results are as noted above.

\subsection{Plans for the Next Quarter}

5.1 Initiate sell test of grout. This activity was delayed from starting during the reporting period due problems associated with fabricating the test molds. The molds have been completed and testing with commence as soon as possible.

5.2 Continue strength testing to assess long term grout strength development.

5.3 Initiate periodic sampling of MEA ash to determine ash variability with time; also 
investigate procedures for alerting users to changes in ash characteristics.

5.4 Initiate tests of grouts to which admixtures have been added to inhibit segregation of flowing mixtures.

5.5 Continue literature review. 


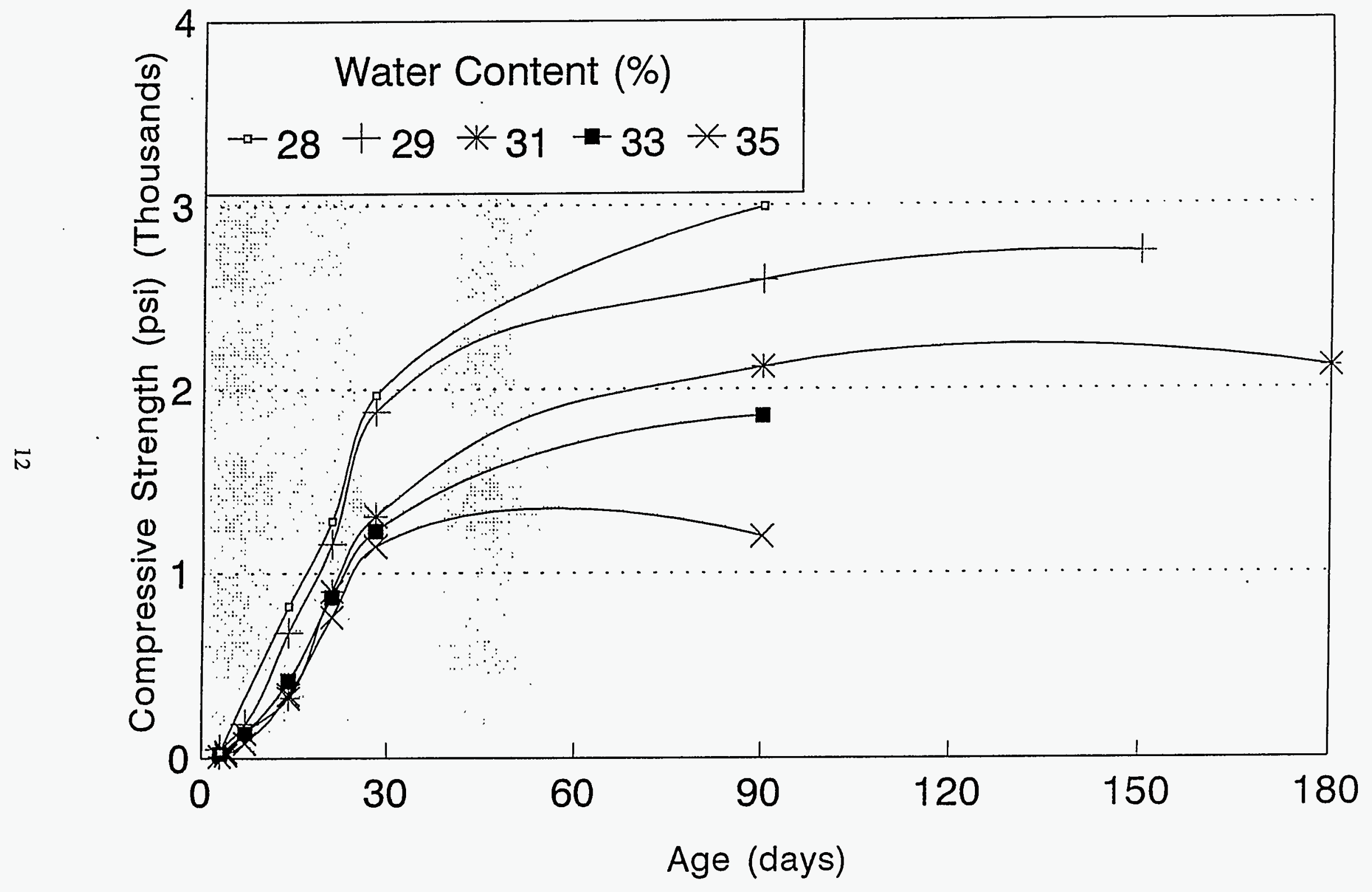

Figure 1 Compressive Strength vs. Age $50 / 50$ Blend of Solids

Tap Water 


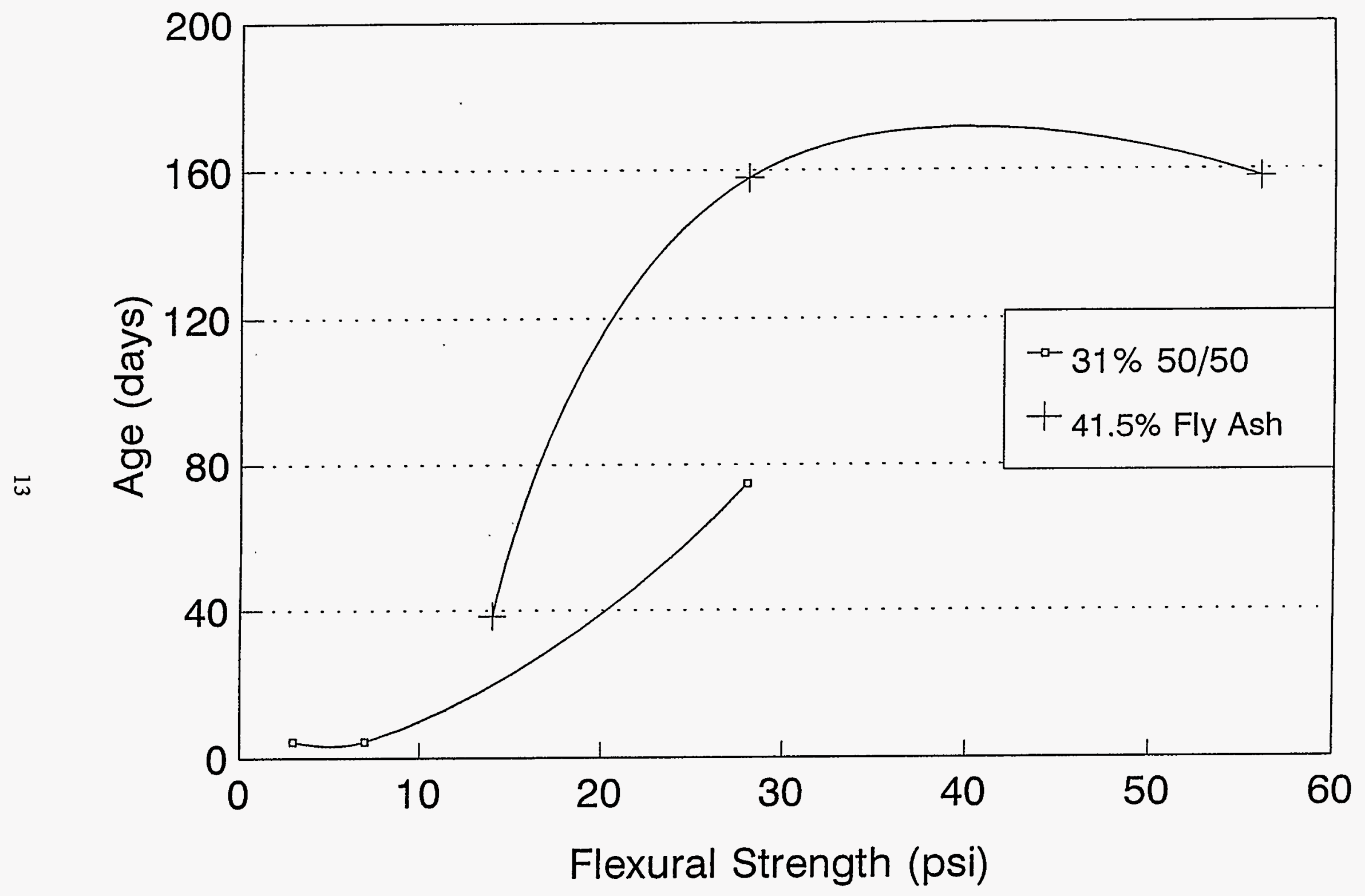

Figure 2

Flexural Strength vs. Time 50/50 Blend and Fly Ash Only

Tap Water 


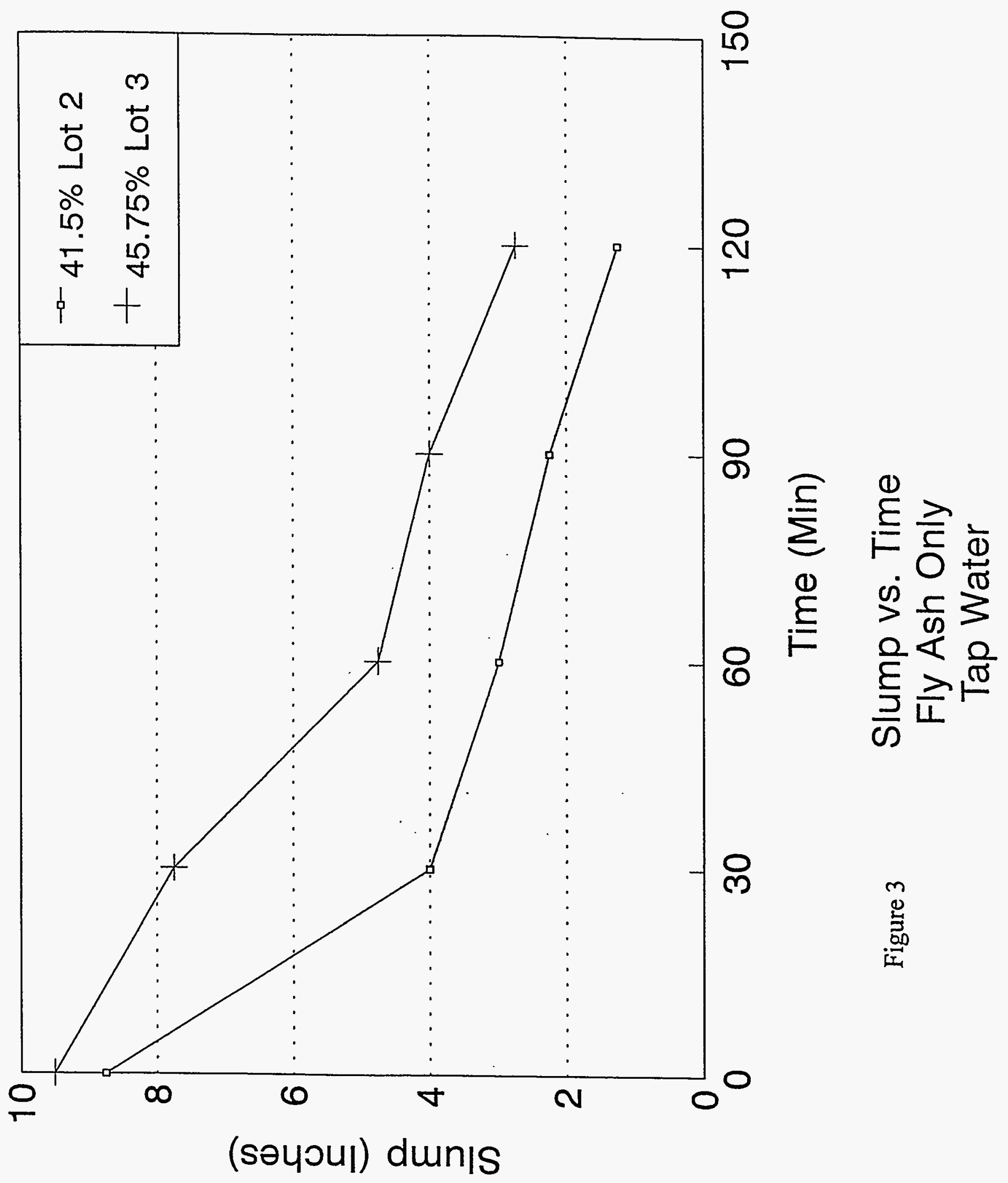




\section{B. Grout Characterization}

\subsection{Task Descriptions}

1.1 Literature Search: This task will involve both manual and computer searches of the literature on several topics. This task will insure that the latest advances in grout technology are incorporated into this project and that no effort is wasted in the duplication of results.

1.2 Grout Characterization: In this task, appropriate viscometric tests will be conducted to determine the relationship between stress and rate of strain, as a function of time and composition of the grout mixture.

1.3 Analytical Modeling: This task is the development of an analytical model to describe the rheology of the grout. This task will provide a constitutive relation that describes the behavior of the grout in agreement with the laboratory results.

1.4 Numerical Modeling: This task includes the adaption of commercially available fluid modeling software to incorporate the rheological model developed in task 1.3. This task will enable the placement of grout to be modeled numerically.

\section{Summary of Accomplishments \& Significant Events}

Literature Search: $100 \%$ complete

Grout Characterization: $40 \%$ complete

Analytical Model: $10 \%$ complete

Numerical Model: $60 \%$ complete

\section{To Date Accomplishments}

The literature search may be considered complete, but new information relevant to the project is continually being revealed. No other tasks are complete to date.

\section{Technical Progress Report}

\subsection{Grout Rheology}

On January 4th, tests were done by Janusz Plucinski of the Department of Chemical Engineering using the Carri-Med CSL rotating parallel-plate rheometer. The tests were performed on samples of FBC ash mixed with glycerin and water respectively. The reason for using glycerin was to try to prevent settling by increasing the viscosity of the liquid portion of the mix. Mix proportions were specified as weight of liquid per total weight of suspension and 
were $57 \%$ for the glycerin mix and $43 \%$ for the water mix. Tests were performed using a shear stress sweep with a rise time of 200 seconds, a peak hold time of 30 seconds, and a decline time of 200 seconds. The rising stress curve can be seen in Figure 4. The peak hold, and declining stress portions of the test are to determine if the material is time dependent, which the glycerin sample was not. From the results of this first test we found that the glycerin solution followed the Herschel - Bulkley constitutive relationship with the form:

$$
\tau=57+483 \Upsilon^{0.89}
$$

With the major units being dynes, centimeters, and seconds. No results were obtained from the sample made with water since the particles settled out of the suspension before the test could be run. Due to the rapid rate of settling, the squeeze-plate plastimeter can't be used for testing unless an admixture which controls settling is included in the mix.

Tests have been done on the flowability of the grout using an open-ended cylinder 6" high by $3^{\prime \prime}$ in diameter. In this test the cylinder is placed on a flat surface and filled with the grout. Then the cylinder is slowly lifted, letting the grout flow from the bottom. The diameter of the spread is taken in two perpendicular directions and the average is recorded. Currently, tests have been done using samples of fly ash only and a mix consisting of a $50 / 50$ blend by weight of fly ash and bottom ash. In each case tests have been done at varying water contents with a constant temperature, and also at a constant water content and varying temperature. During this test we have found that the flow properties of the fly ash have changed from one batch of fly ash to the next (see figure 5), and the same is apparently true for the bottom ash. We feel this test may be useful during the placing of the grout in the field as a measure of the spread that will occur from different batches of the mix.

The other major area of interest this quarter has been the simulation of a "broken-dam". For this test, a clear acrylic tank with dimensions of $20 \mathrm{~cm}$ wide by $40 \mathrm{~cm}$ high by $100 \mathrm{~cm}$ long was constructed. A vertical sliding gate positioned $20 \mathrm{~cm}$ from the end was used to represent the dam. The $20 \mathrm{~cm}$ reservoir behind the dam is filled to a height of $30 \mathrm{~cm}$ The gate is then quickly removed allowing the grout to flow along the length of the box. The test is recorded using a VHS video recorder providing a plan and profile view of the test. A profile of the flowing column is taken from the playback screen at 0.1 second intervals. This test, like the flow cylinder test has also shown different flow characteristics between different batches of materials.

\section{Numerical Model}

A PHOENICS simulation of the "broken-dam" model described above has been created and is currently being evaluated. The simulation is unsteady and uses 400 time steps to simulate the first 2 seconds after the dam has been removed. The 2-dimensional model domain has the same dimensions as the actual testing box with a $25 \times 10$ non-uniform grid. The grout material is simulated as a Herschel-Bulkley fluid and the remainder of the domain is initially filled with air with room temperature properties. The only boundary condition currently imposed in this simulation is an outlet across the top of the domain that represents the open top of the testing box. All other boundaries are free-slip wall boundaries. The model does not 
simulate the upward motion of the plate as it is withdrawn from the box, rather, it specifies the initial rectangular column of grout at time zero, then tracks the slumping of the grout column at subsequent time steps as it moves under the force of gravity. A set of figures is attached that illustrates the simulated movement of a column of a Herschel-Bulkley fluid and a Newtonian fluid (See Figures 6 to 13). The simulated movement of the grout column may be compared to the actual grout movement as recorded with the physical model in the laboratory.

The Herschel-Bulkley fluid model relates the shear-stress $(\mathfrak{r})$ to strain-rate $(\Upsilon)$ as follows:

$$
\tau=\tau_{y}+K(\Upsilon)^{n}
$$

where the three physical parameters, the yield stress $\left(\tau_{y}\right)$, the consistency index $(K)$, and the flow behavior index (n), must be uniquely specified to fully characterize the grout. It is hoped that by varying the values of these parameters in the PHOENICS simulation, the numerical result can be made to match the experimental result, thereby resulting in the determination of the physical parameters. The process of finding the correct combination of parameter values is slowly proceeding by trial and error. A satisfactory parameter combination has not yet been found that produces acceptable agreement between the numerical and experimental results. Once a suitable combination is found, the same combination can be used to simulate flow of the grout in any geometry including full-scale mine simulations.

It is unclear at this time what kind of boundary condition should be applied at the domain walls. As mentioned above, a free-slip condition is currently being used, but for most fluids, a no-slip condition is required to satisfy the well known no-slip condition that actually exists. However, with a suspension like FBC ash grouts, the suspending fluid may have zero velocity at the wall (ie: no-slip), but there is no restriction on the solid particle velocity. This means that the solid particles may slide along the wall. As a consequence, it appears that the grout mixture will violate the no-slip condition. There will be some retarding friction at the wall, but it is unclear at this time how to quantify the magnitude of resistance. An investigation of available reference sources has been initiated to uncover what knowledge of this phenomena exists in the literature.

A computer hardware problem was described in the previous quarterly report that concerns the defective Intel Pentium chip. It is necessary to replace the defective computer chip in the machine being used in order to perform the numerical simulations reliably. The manufacturer has been contacted but the replacement chip has not yet arrived. 


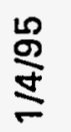

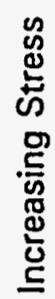

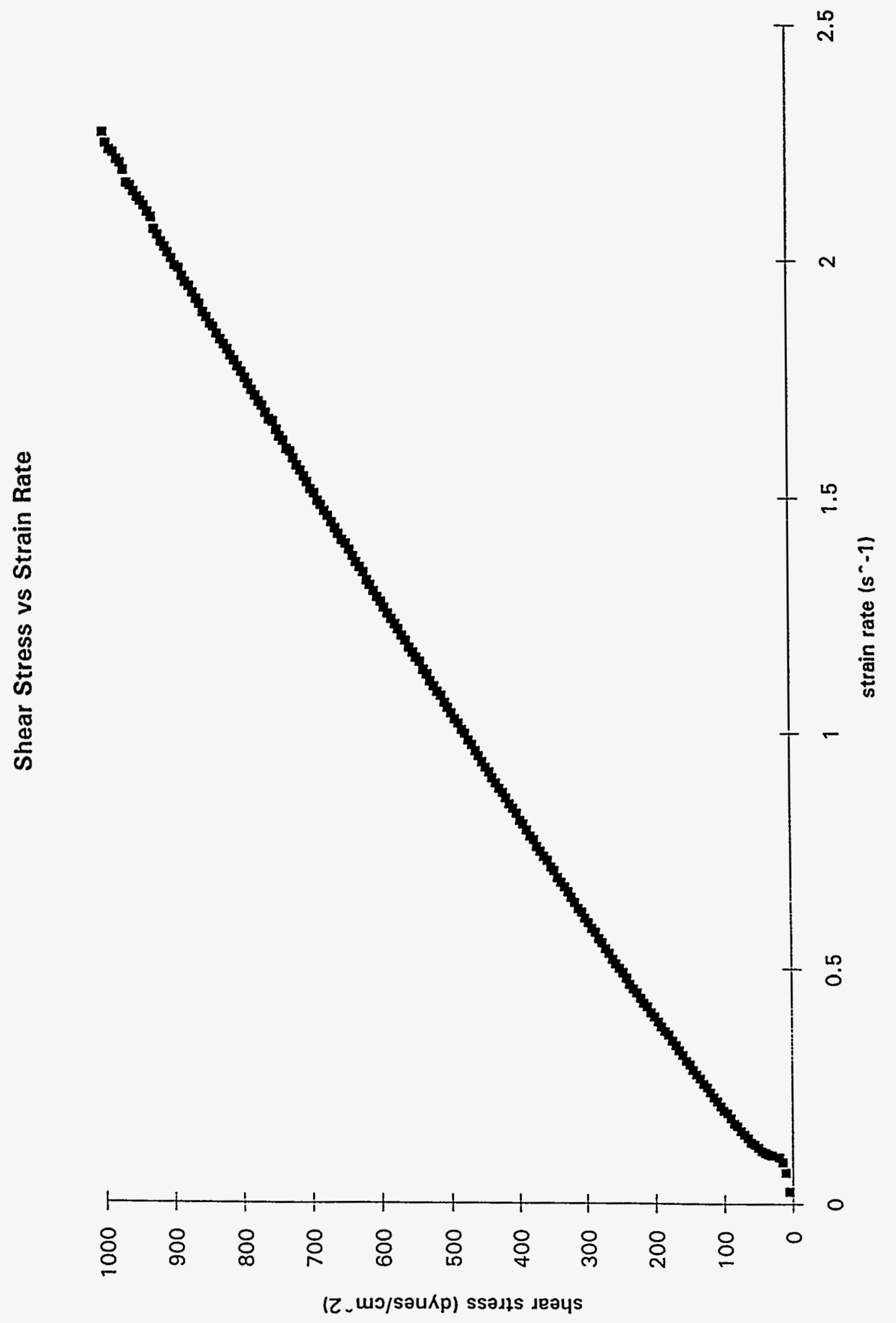




\section{Cylinder Spread Tests: Flyash Only}

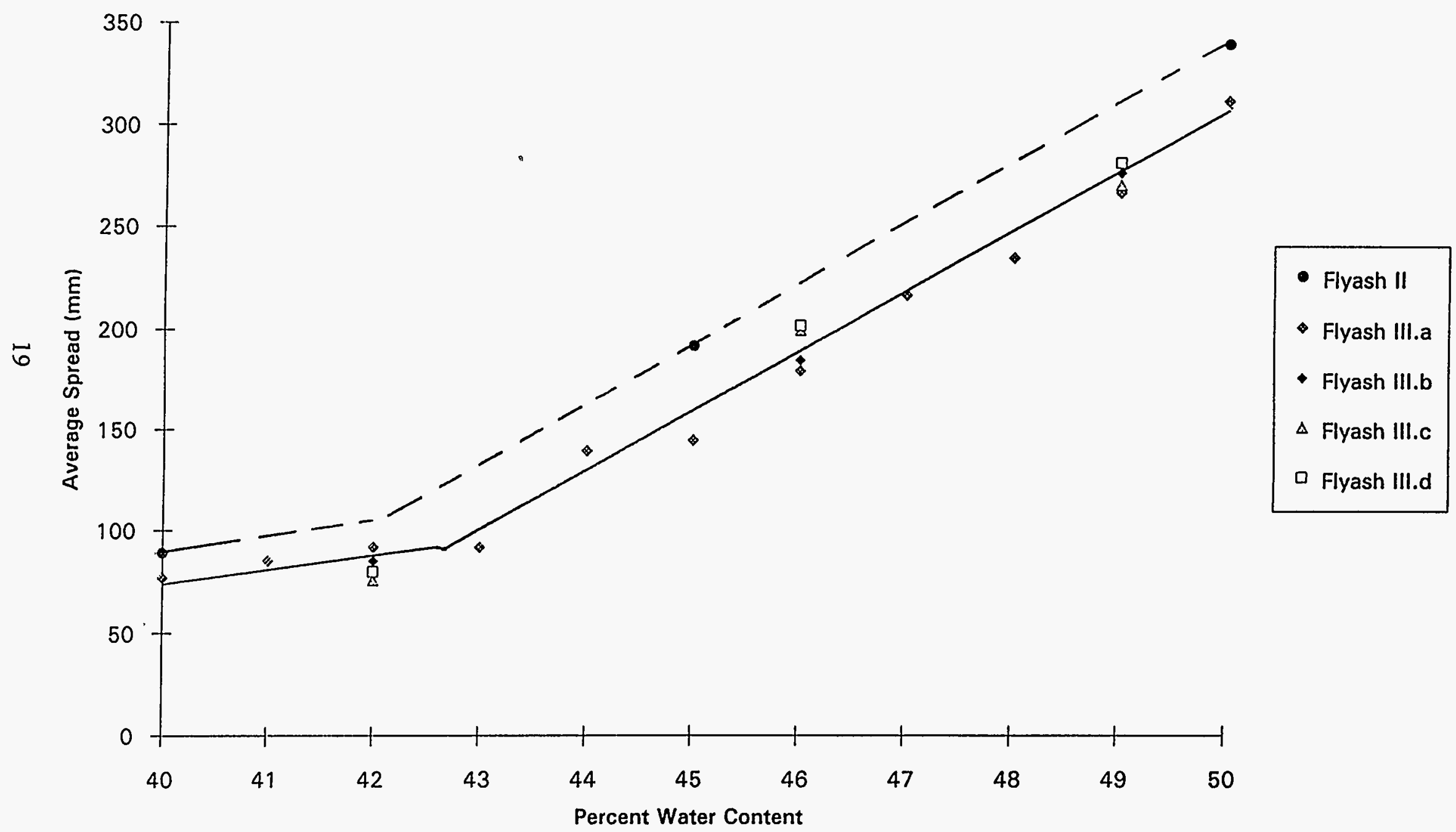

Figure 5 


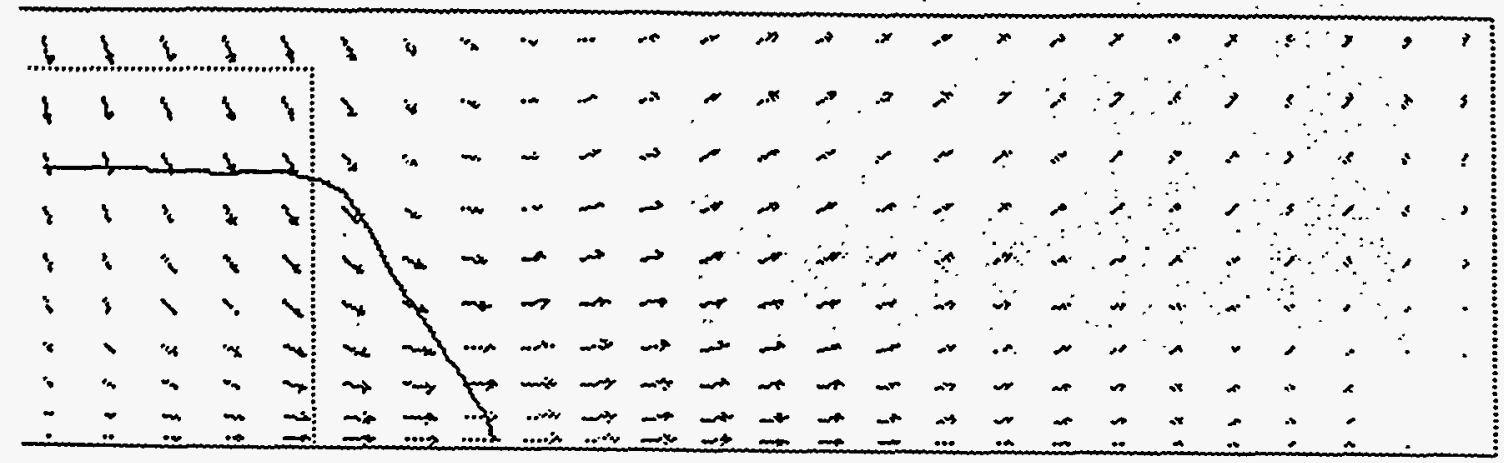

Herschel-Bulkley Fluid

$4.24 \mathrm{~m} / \mathrm{s}$

Min:

SLUMPING OF H-B FLUID IN AN OPEN BOX
PHOTON:

Uector

0.85

0.14

0.23

0.32

0.41

0.49

0.58

9.6?

0.76

0.85

0.94

$1: 03$

1.12

1.20

1.29

$\mathrm{m} / \mathrm{s}$

2

$\longleftrightarrow Y$

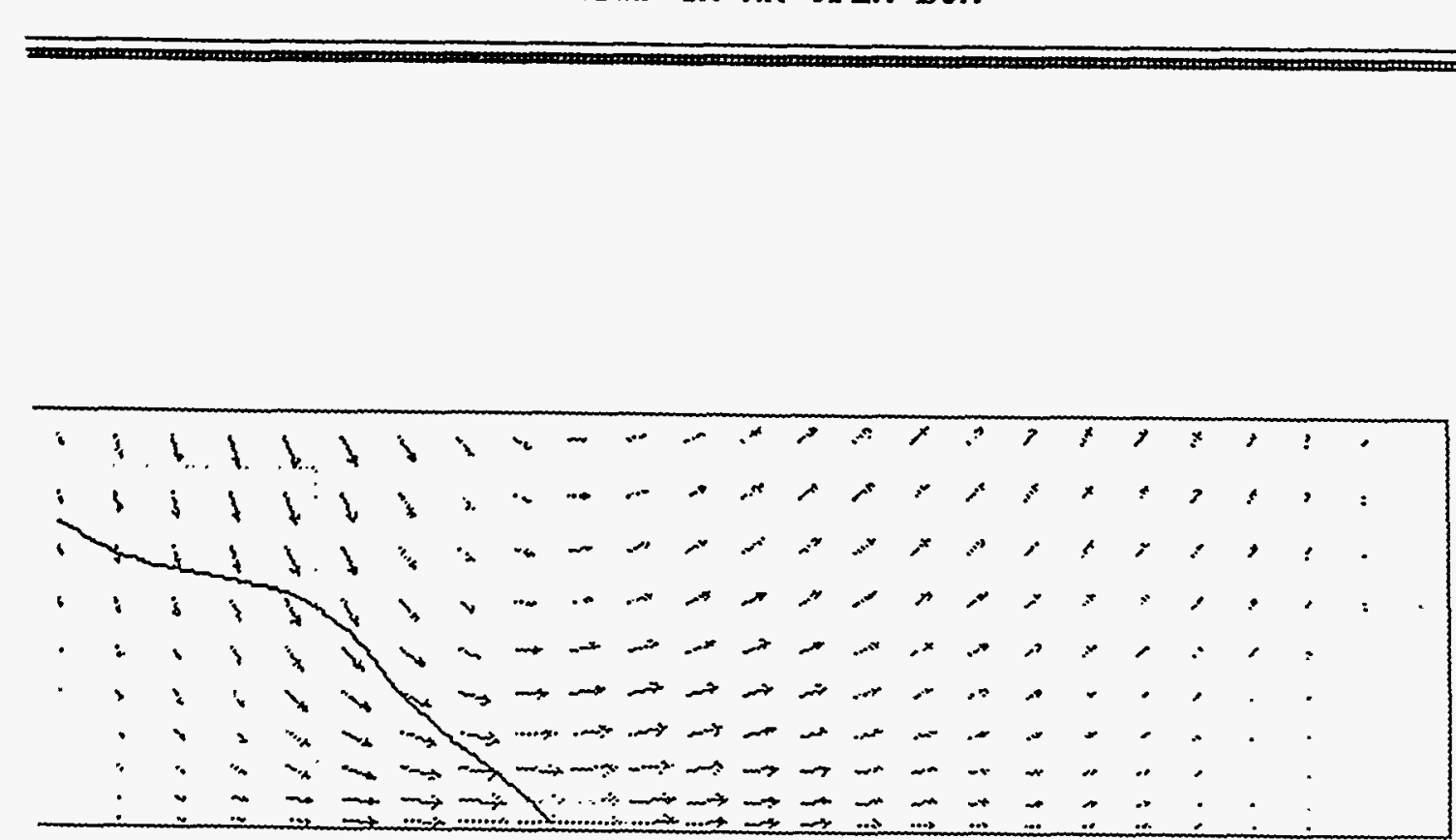

PHOTON

Vector

0.01

0.14

0.27

0.46

0.53

0.66

0.78

0.91

1.84

1.17?

1.30

1.43

1.56

1.69

1.82

newtonian

$\mathrm{m} / \mathrm{s}$

$\stackrel{Z}{\longrightarrow}$ 


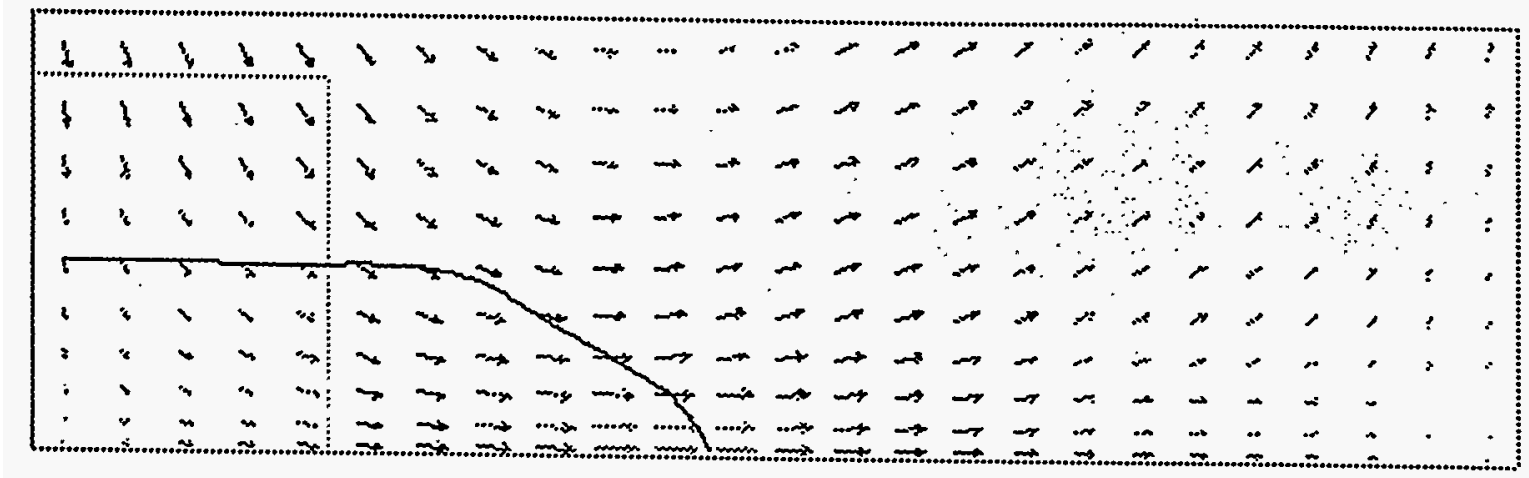

PHOTON

Herschel-Bulkley Fluid

Time $=0.25$ sec .

Vector

0.08

0.17

0.27

0.36

0.45

0.54

0.64

0.73

0.82

0.91

1.01

1.10

1.19

1.29

1.38

$\mathrm{m} / \mathrm{s}$

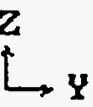

SLUMPING OF H-B FLUID IN AN OPEN BOX

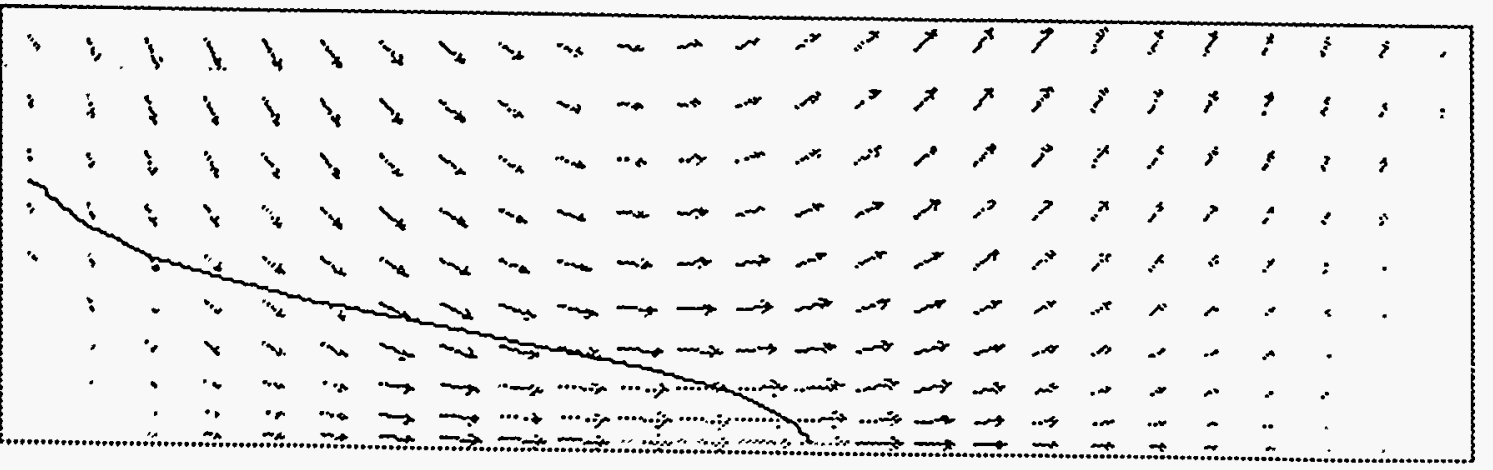

newtonian

\section{PHOTON}

Vector

0.0

0.2

0.3

0.4

0.6

0.7

0.9

1.0

1.1

1.3

1.4

1.5

1.7

1.8

2.0

$\mathrm{m} / \mathrm{s}$

$4.24 \mathrm{~m} / \mathrm{s} \quad \mathrm{Min}$ :

$\operatorname{Max}:+\cdots: \cdots$ 


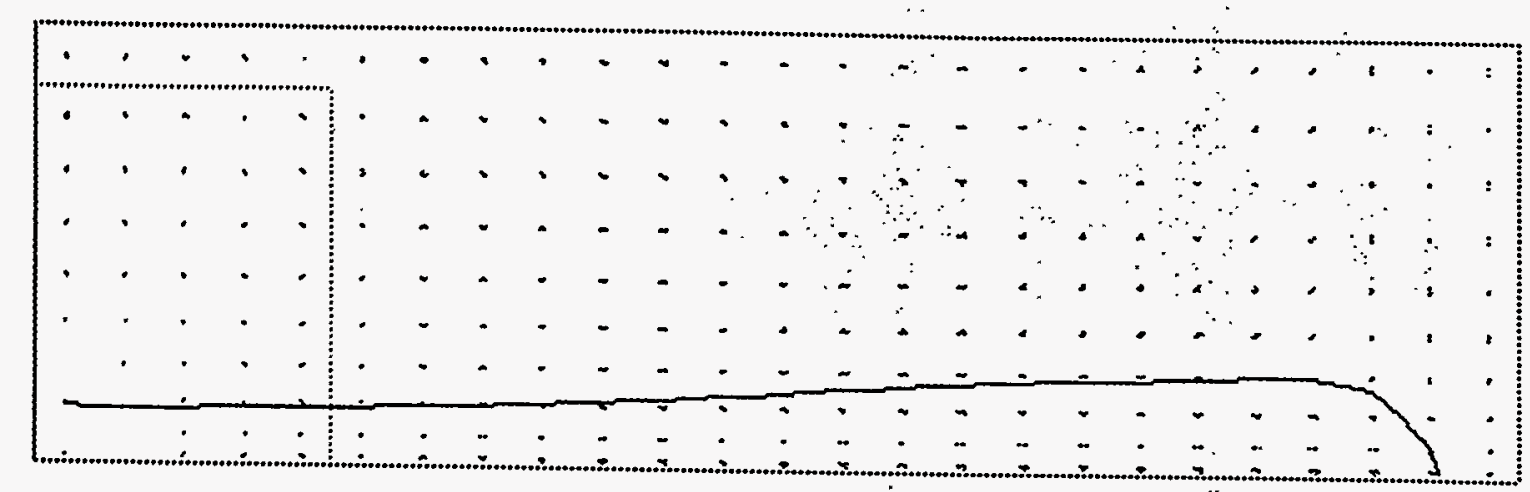

Herschel-Bulkley Fluid

Time $=1.0 \mathrm{sec}$.

PHOTON

Vector

0.01

0.83

0.85

Q.86

0.08

0.89

0.11

0.12

0.14

0.15

0.17

0.18

อ. 20

0.21

0.23

$\mathrm{m} / \mathrm{s}$

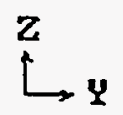

SLUMPING OF $\mathrm{H}-\mathrm{B}$ FLUID IM AN OPEN BOX

Max: $2 ., 3 \% \cdots$

Vector

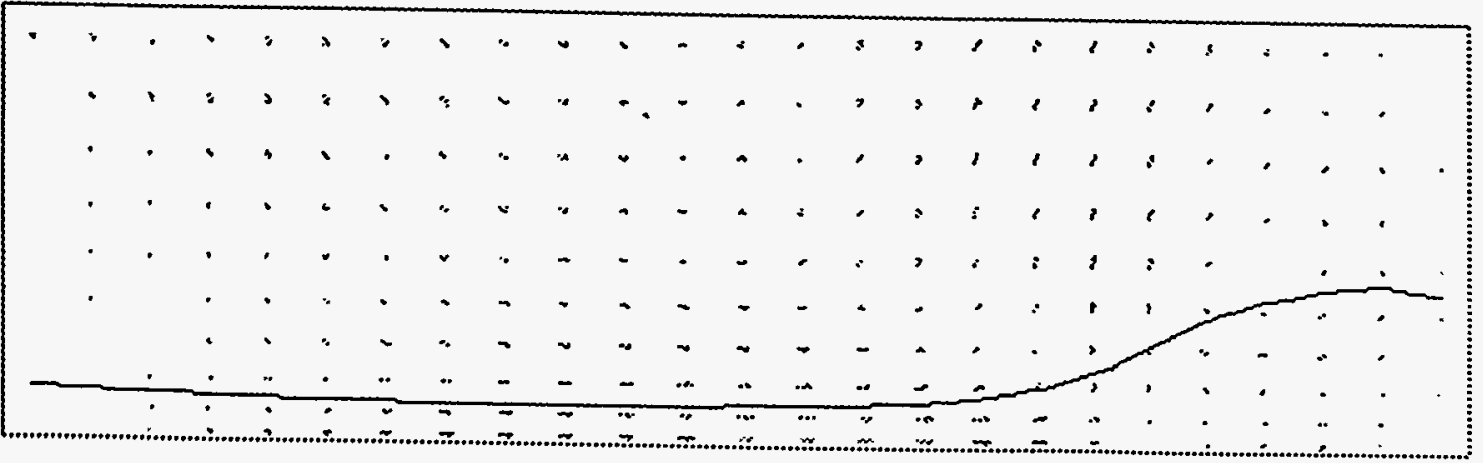

Q. 83

Q.07

0.18

0.14

0.18

0.21

0.25

0.29

0.32

0.36

0.40

0.43

0.47

0.50

0.54

newtonian 


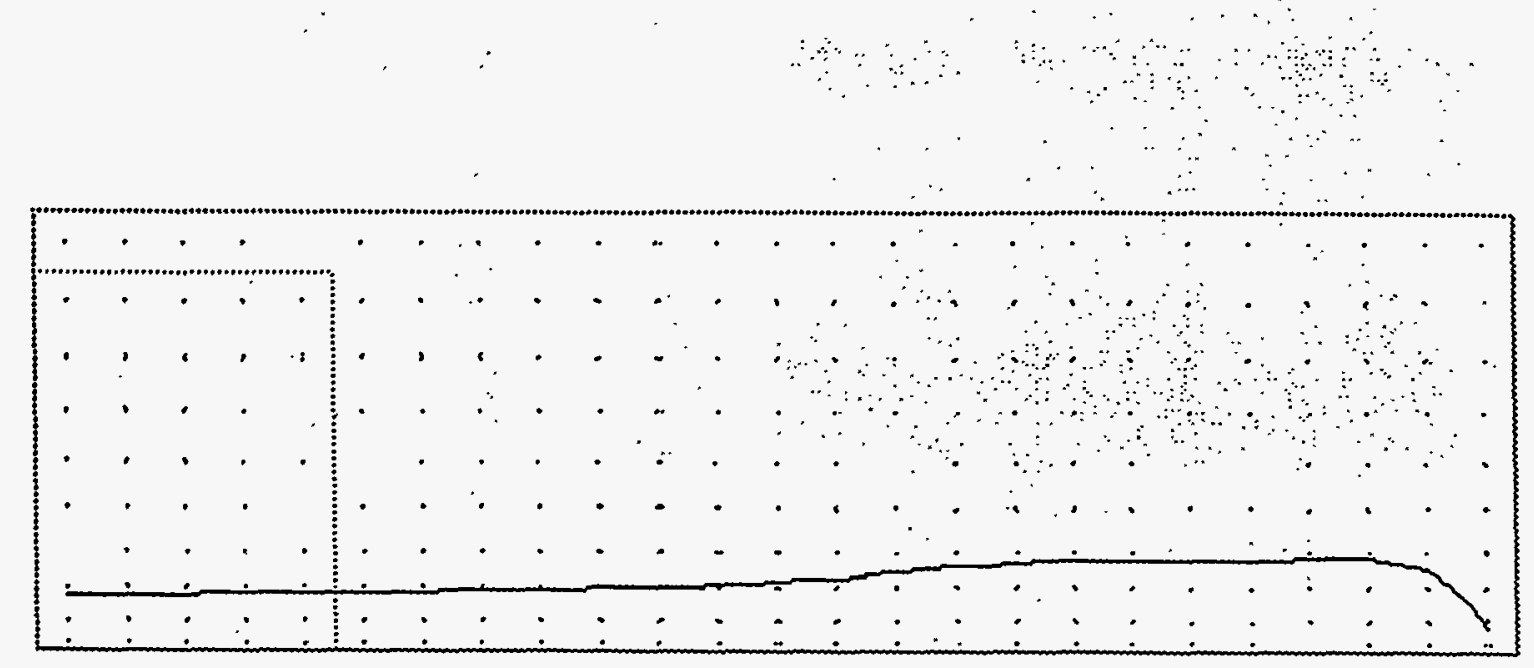

Herschel-Bulkley Fluid Time $=1.5 \mathrm{sec}$.

PHOTON

Vector

0.084

0.908

0.012

0.016

0.020

0.024

0.028

0.031

0.035

อ.

0.043

0.042

0.01

0.055

0.059

$\mathrm{m} / \mathrm{s}$

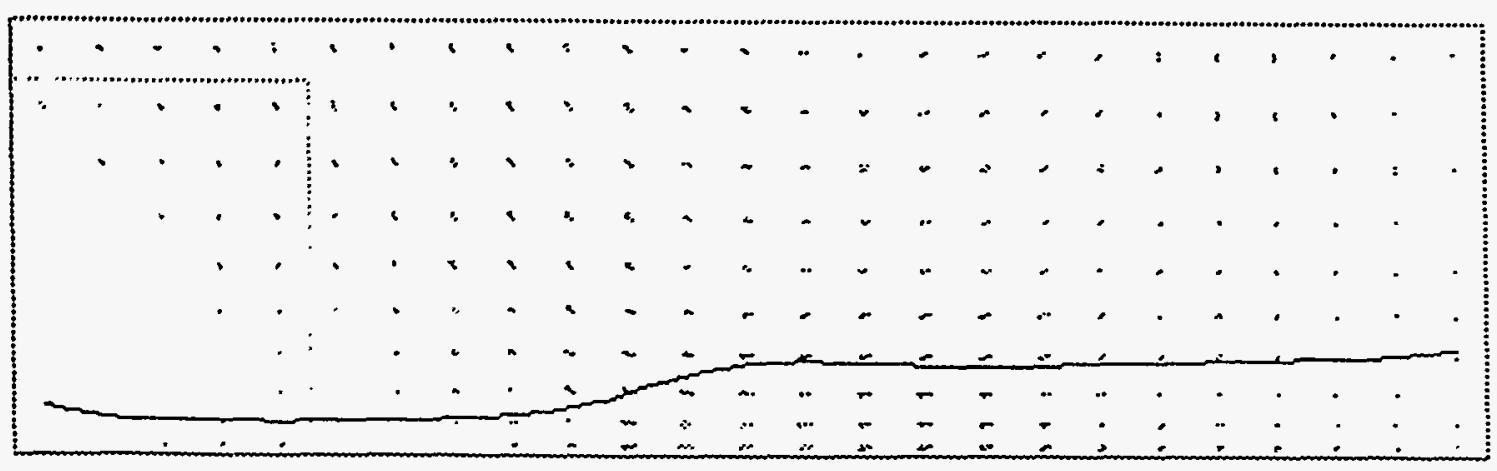

PHOTON

Vector

g. 01

0.04

0.68

0.11

0.15

0.18

B. 21

0.25

0.28

0.31

0. 35

0.38

0.42

0.45

8.48

newtonian

$\mathrm{m} / \mathrm{s}$

$\rightarrow 4.24 \mathrm{~m} / \mathrm{s} \quad \mathrm{Min}:$

$\operatorname{Max}: 4 . . \%$ 


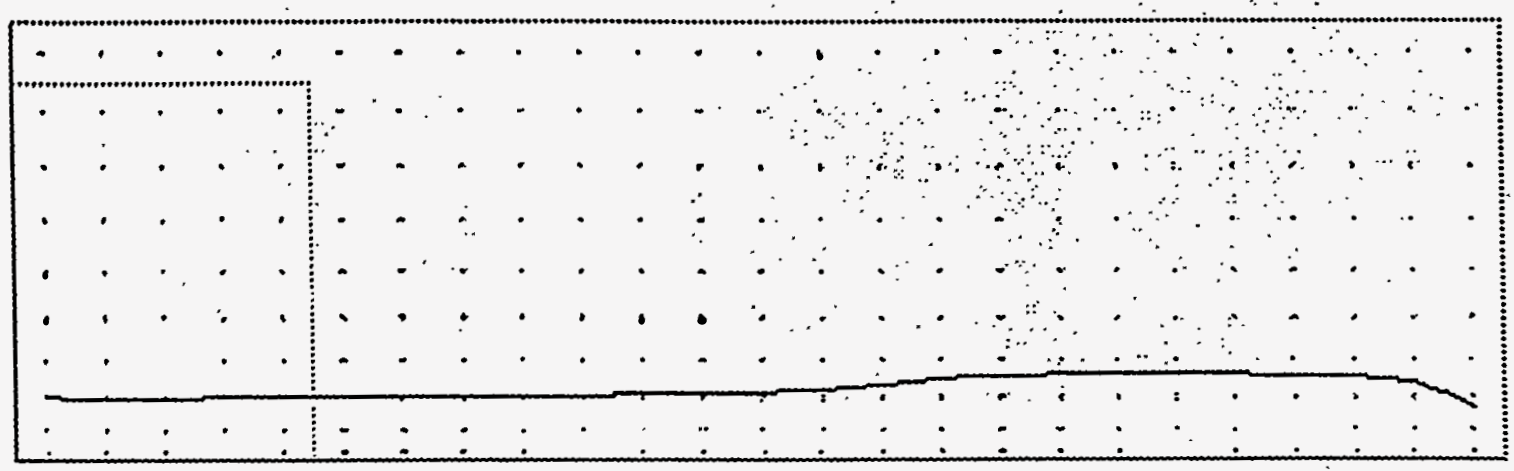

Hersche1-Bulkley Fluid

Time $=2.0$ sec.

$4.24 \mathrm{~m} / \mathrm{s}$

Min: $: 43 \%$

Max: $3 . พ \frac{2}{2}$

pHoToat

SLUMPING OF H-B FLUID IN AN OPEN BOX

Vector

0.083

0.007

0.010

Q.814

0.618

8.022

0.026

0.038

0.034

0.038

0.042

Q.046:

0.050

0.054

0.058

$\mathrm{m} / \mathrm{s}$

2

$L_{4}$

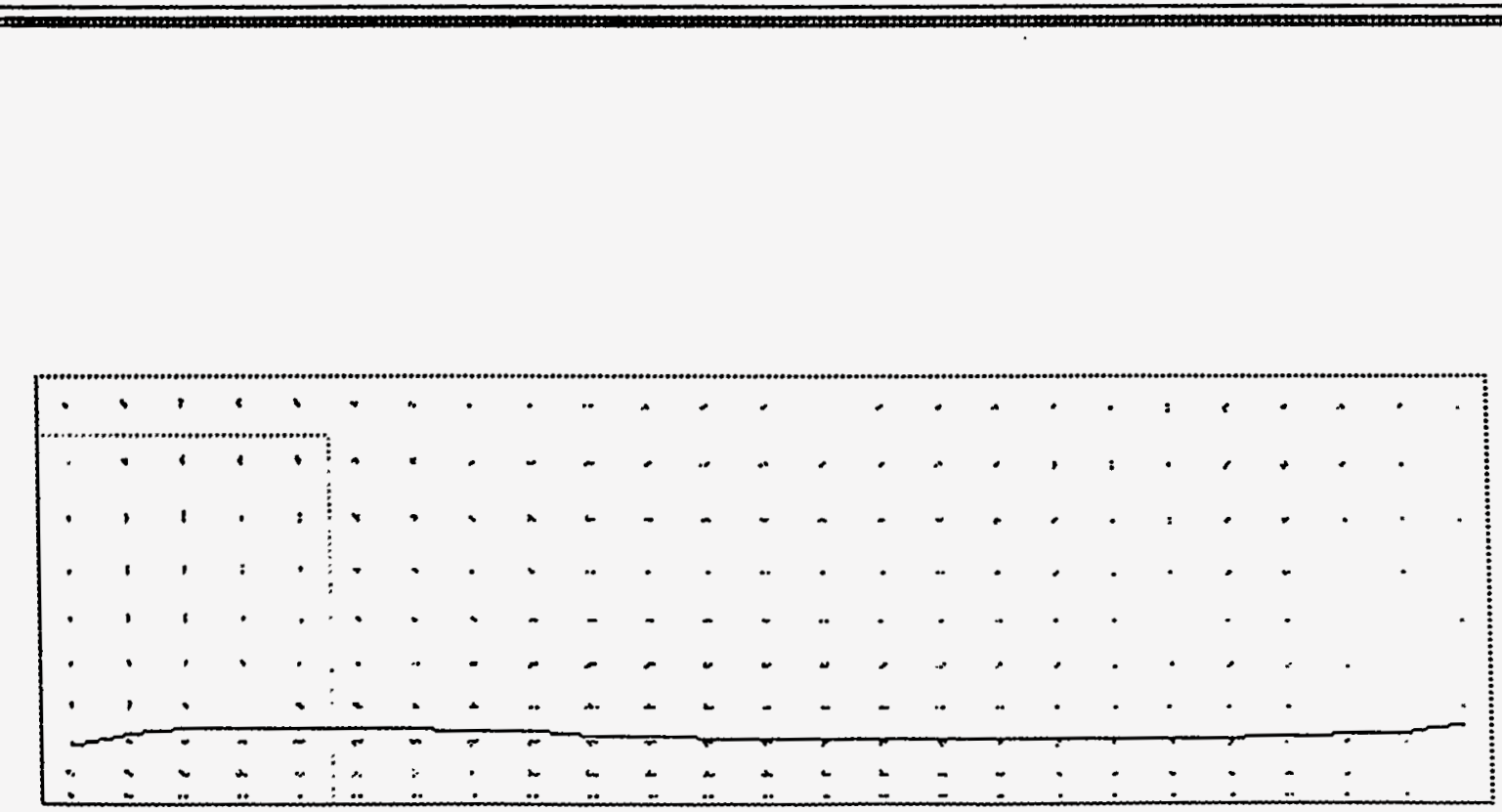

newtonian 


\section{Water Quality Monitoring}

\subsection{Task Description}

\section{Baseline Water Quality Monitoring}

This task is to monitor baseline water quality of the acid mine drainage (AMD) from the Longridge and Fairfax Mines prior to grouting. A flow monitoring and sampling station has been set up at the Longridge Mine and a precipitation gauge has been established between the two mines.

\subsection{Summary of Quarter's Accomplishments \& Significant Events}

Water quality monitoring and sampling continued as planned. Data is presented and discussed in some detail below. Flows from the Longridge Mine varied significantly during the quarter from a weekly low of $8.79 \mathrm{gpm}$ to a high of $121.4 \mathrm{gpm}$ and averaged $52.2 \mathrm{gpm}$. This was a significant increase in flow over last quarter where the flow averaged only $24.6 \mathrm{gpm}$. The higher flows in this quarter resulted in a reduced concentration of pollutants due to dilution of the acid water leaving the mine. For example, the iron concentration fell to an average value of $174 \mathrm{mg} / \mathrm{l}$ this quarter as compared to $194.9 \mathrm{mg} / \mathrm{l}$ last quarter. However, the actual average pounds of pollutants leaving the mine was higher this quarter due to the higher flows.

\subsection{To Date Accomplishments}

Accomplishments to date include choice of parameters to sample, design of the sampling station, procurement of equipment, site preparation, installation and shake down of equipment, initiation of sampling and preliminary analysis of data to date.

\subsection{Technical Progress Report}

Results of monitoring flow, precipitation and water quality are discussed below. In addition, several issues related to monitoring activities at the site are described.

\subsection{Flow and Precipitation Monitoring}

Average weekly flow (gpm) from the Longridge Mine is shown in Table 1 and Figure 14. Flow varied widely during the quarter from a weekly low of $8.79 \mathrm{gpm}$ to a high of 121.4 and averaged $52.2 \mathrm{gpm}$. This was much higher than last quarter when the flow averaged only $24.6 \mathrm{gpm}$. Precipitation during this quarter averaged 0.69 inches per week as compared to 0.38 inches per week in the previous quarter. The rain gauge is not heated and several weeks of data were lost due to problems of freezing. However, data was obtained from the Morgantown Lock and Data weather station to provide precipitation data for the missing weeks.

Daily variation in flow is presented in Figure 15 for the week of January 7 to 14 (Week \# 


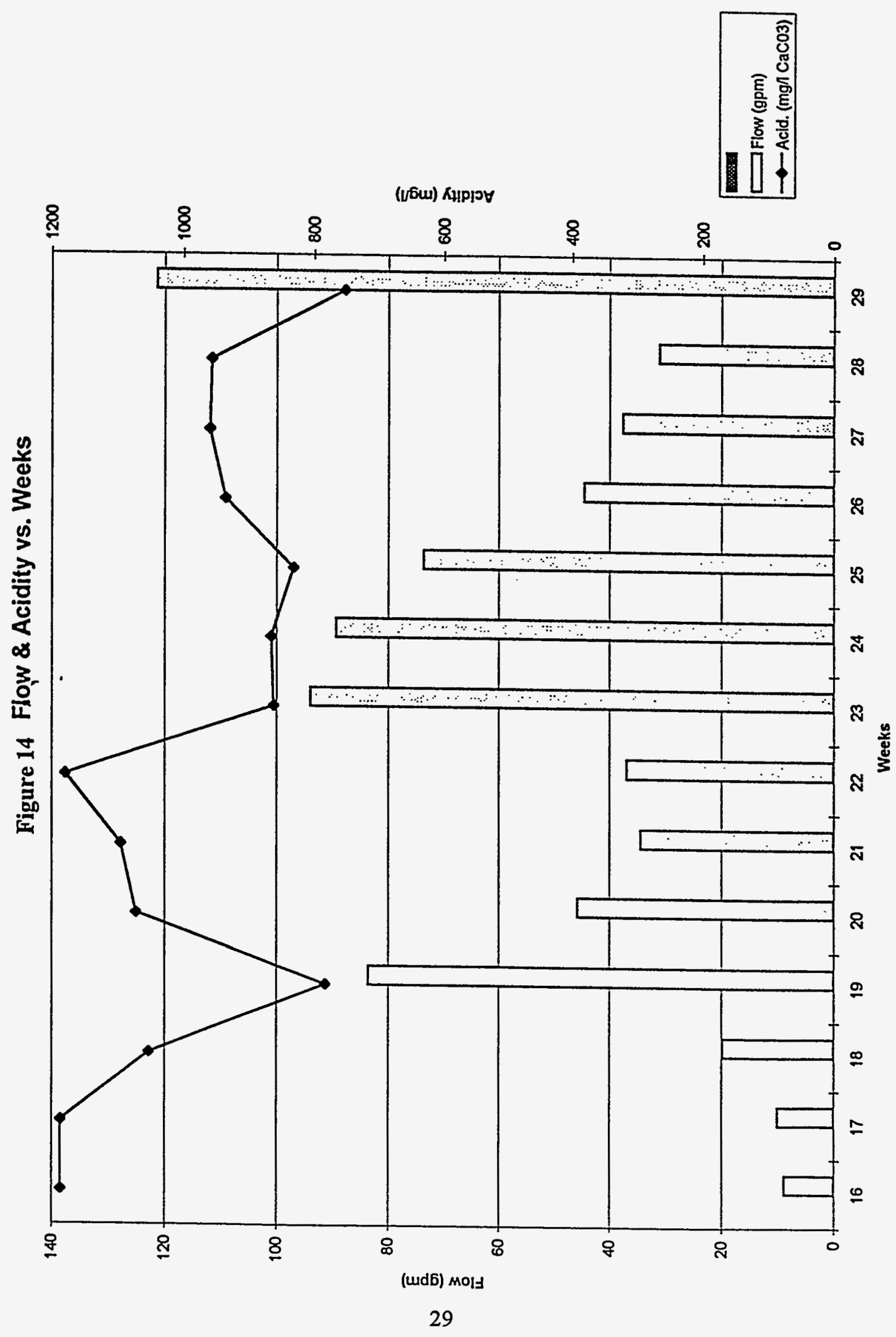




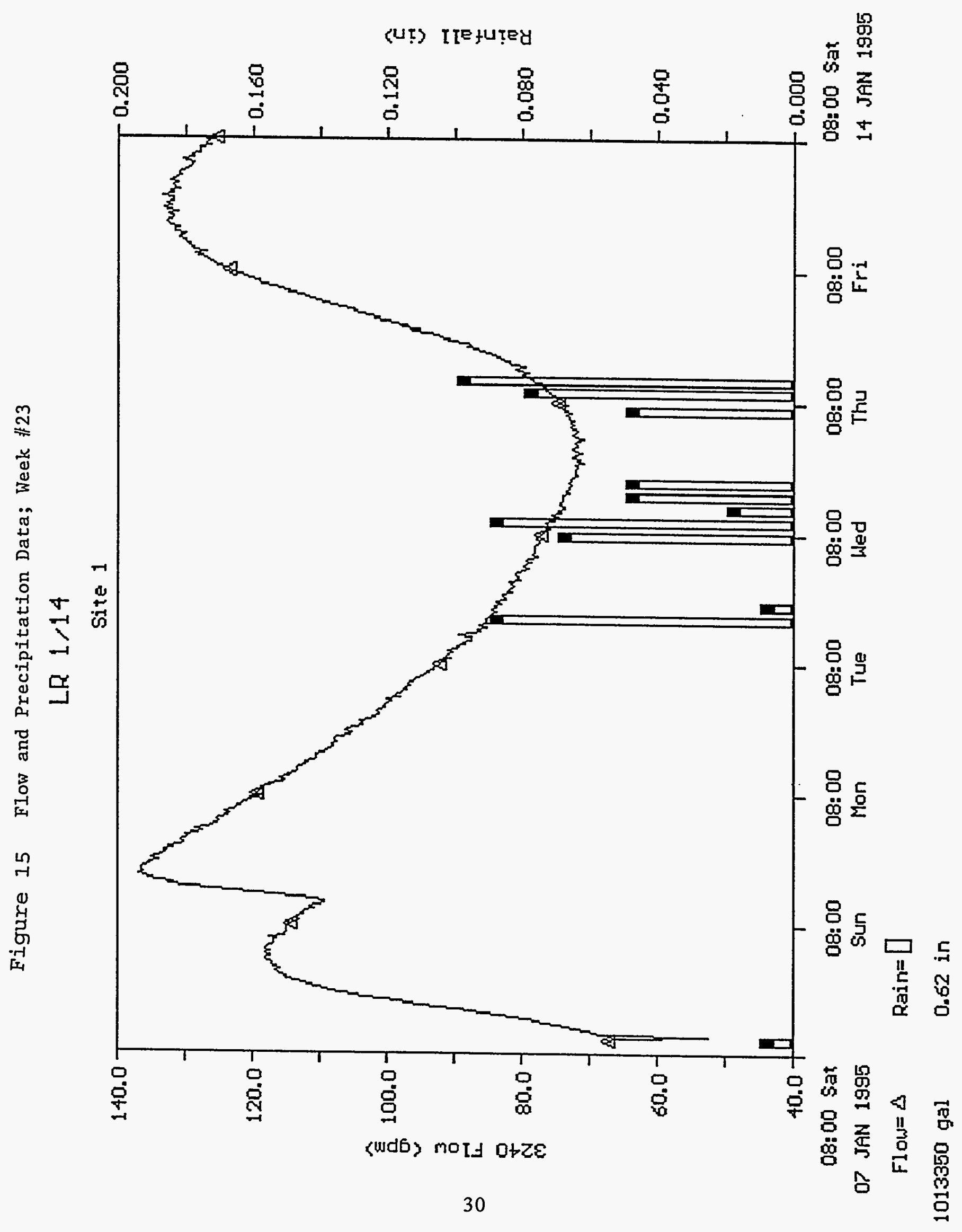




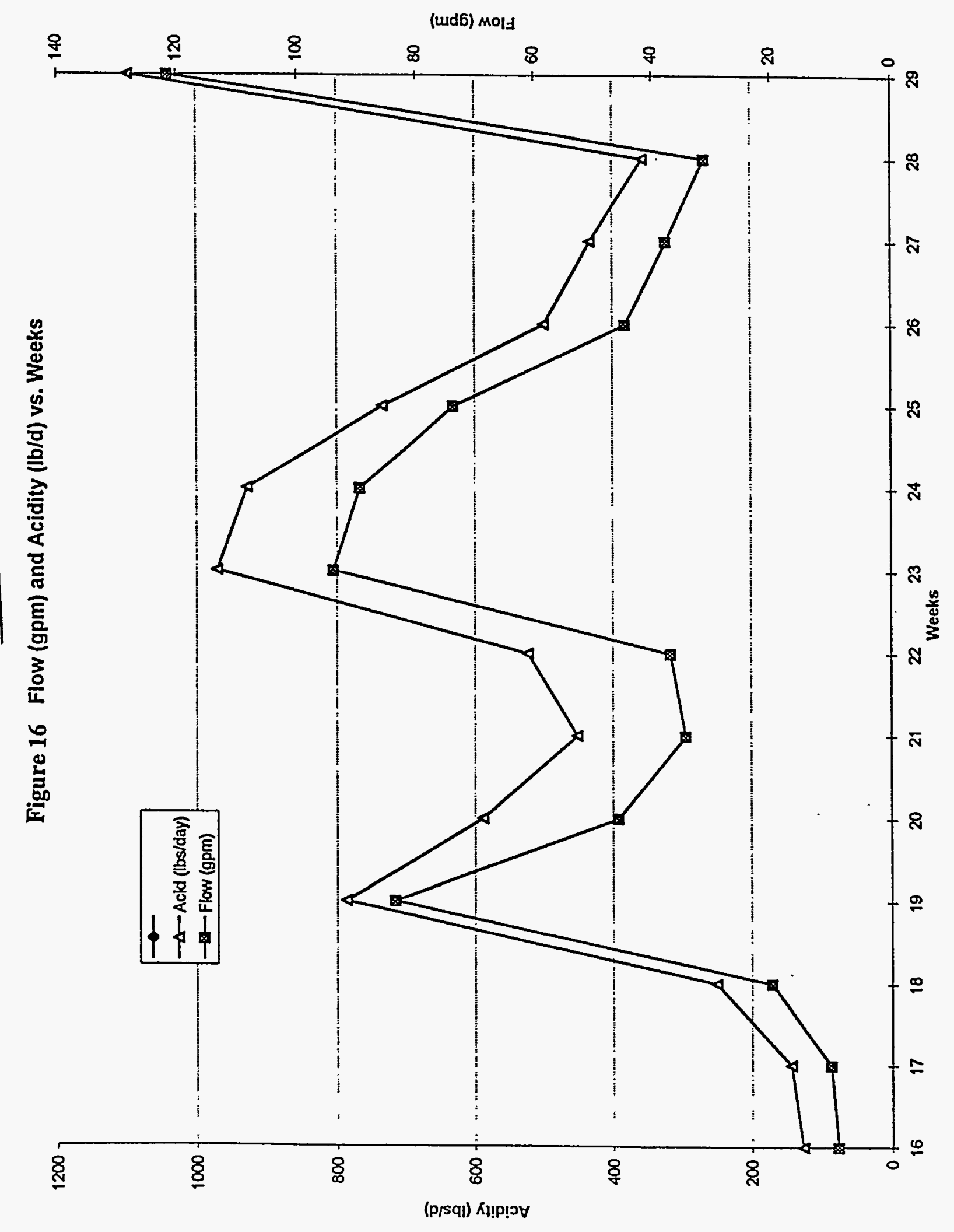




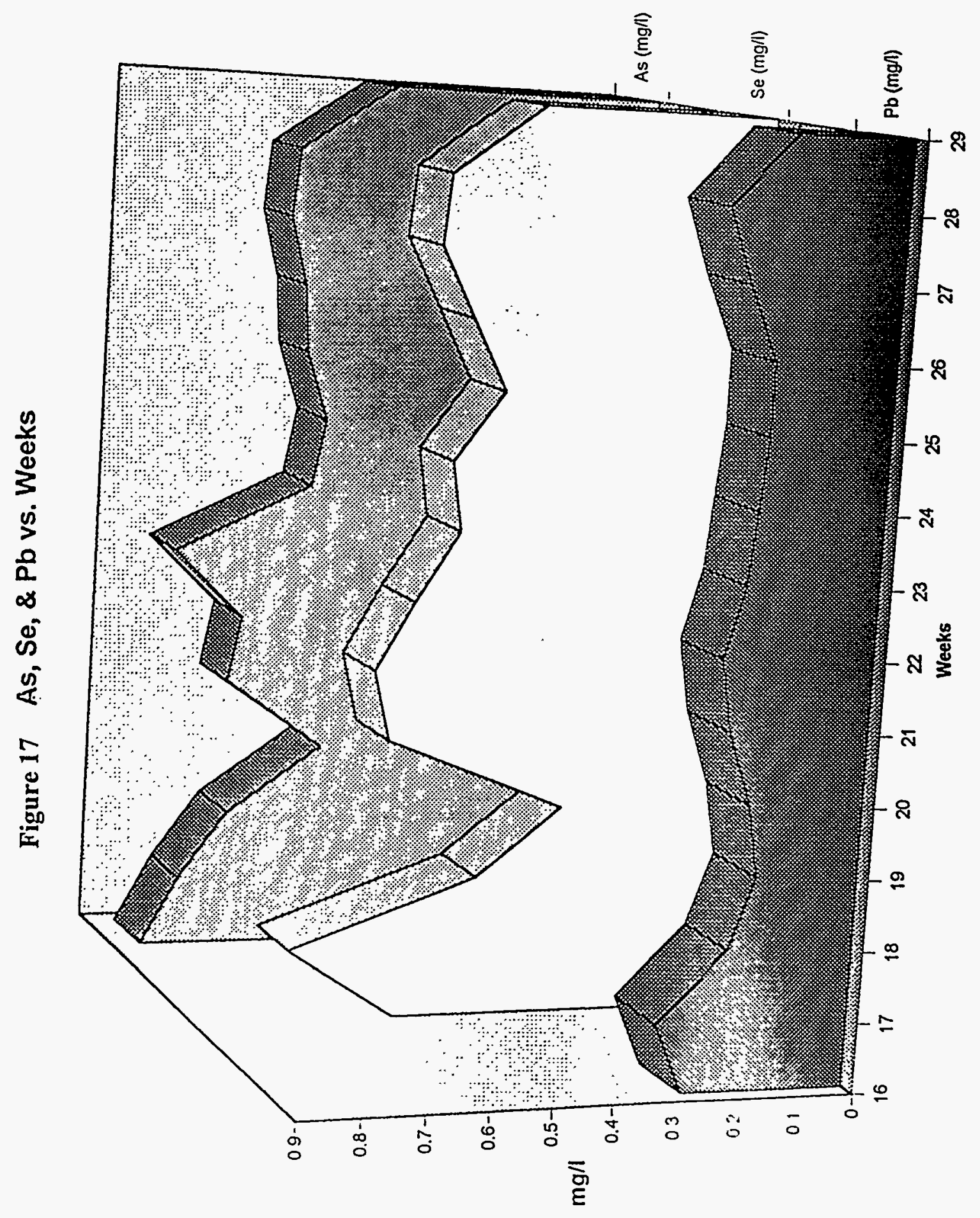




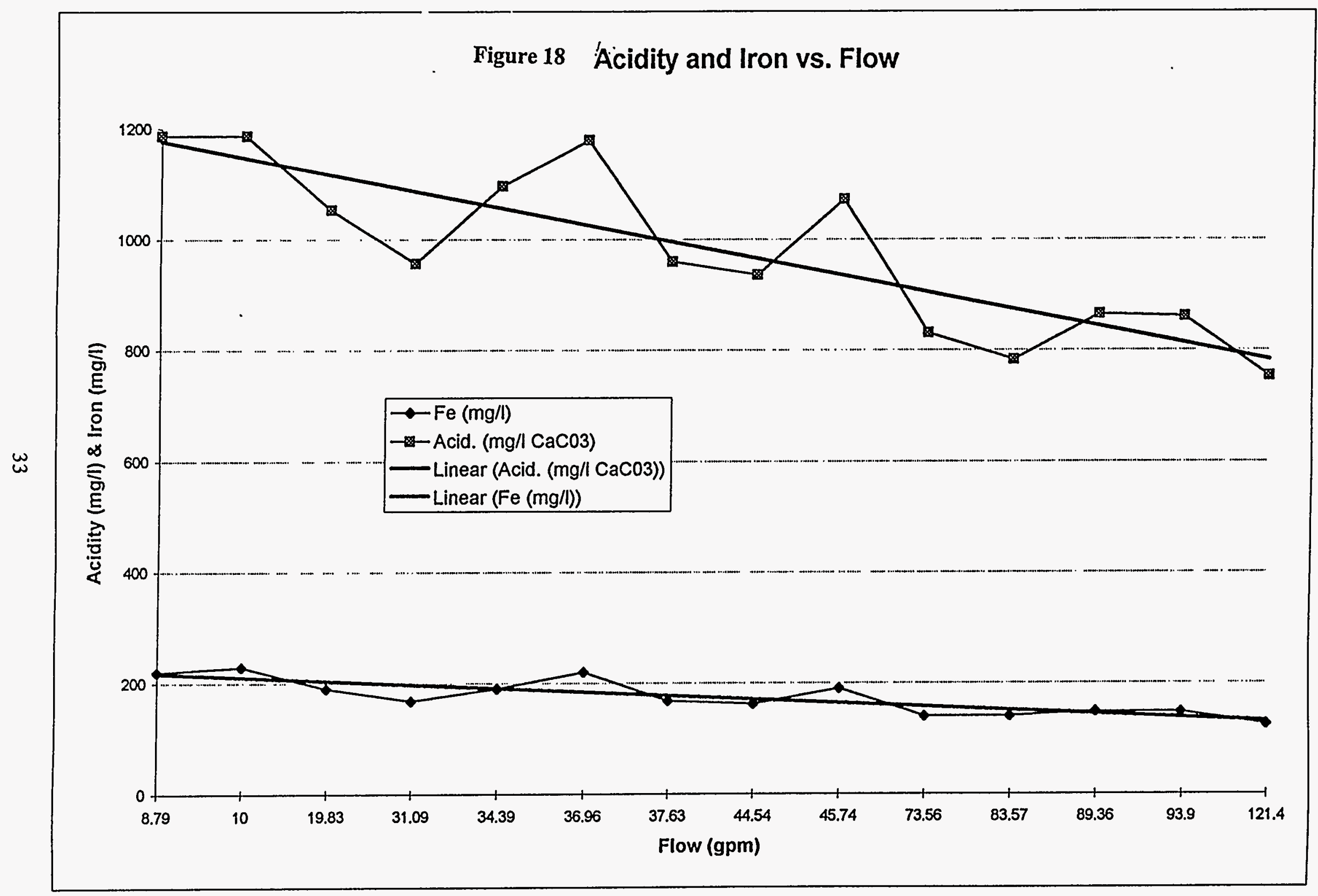




\section{Subsidence Control \& Contaminant Transport}

\subsection{Task Description}

Task 4.0 Grout Strength Requirements

Determine grout strength requirements need to ensure subsidence control.

\section{Task 5.0 Contaminant Transport}

Determine how contaminants will migrate within the grout that is placed in the mine void.

\subsection{Summary of Quarter's Accomplishments and Significant Events}

2.1 Additional mine maps were obtained from Anker Energy for the Longridge mine and Fairfax sites. The preparation of geologic columns and cross-sections at the Longridge and Fairfax mine were completed.

2.2 The work on the contaminant transport modeling was continued.

\subsection{To Date Accomplishments}

3.1 Ground profiles at transverse Sections D - D and E - E of the Fairfax mine were prepared.

3.2 Material Properties for the Fairfax and the Longridge Mines ere established.

3.3 Preliminary calculations were performed to determine the overburden stress at the level of the coal seam.

3.4 Literature related to grout strength requirement was continued.

3.5 Maps were catalogued to show the locations of the cross-sections and core holes.

3.6 Several titles of pertinent publications on Contaminant Transport Modeling were identified. However, these publications have not been collected yet.

3.7 A search for potential software to be used in the Contaminant Transport Modeling was completed.

3.8 Literature review for the task on Acid Mine Drainage was continued.

\subsection{Technical Progress Report}


Titles of several publications pertaining to Contaminant Transport Modeling have been identified.

\subsection{Plans for Next Quarter}

5.1 Continue work on the contaminant transport part of the project. Obtain necessary software for this task.

5.2 Continue calculations to determine grout strength requirements.

5.3 Continue literature review and technical evaluations. 


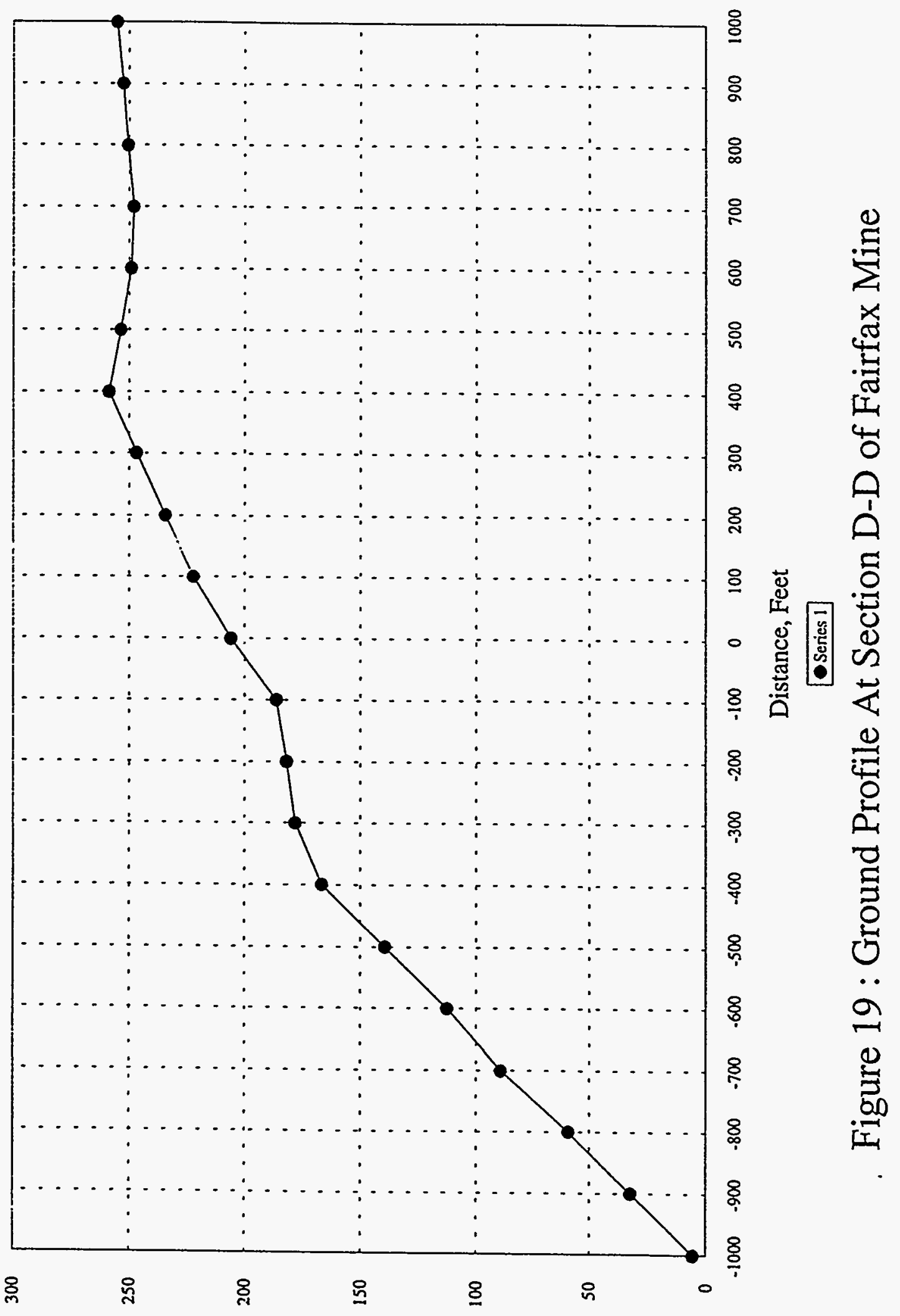

 


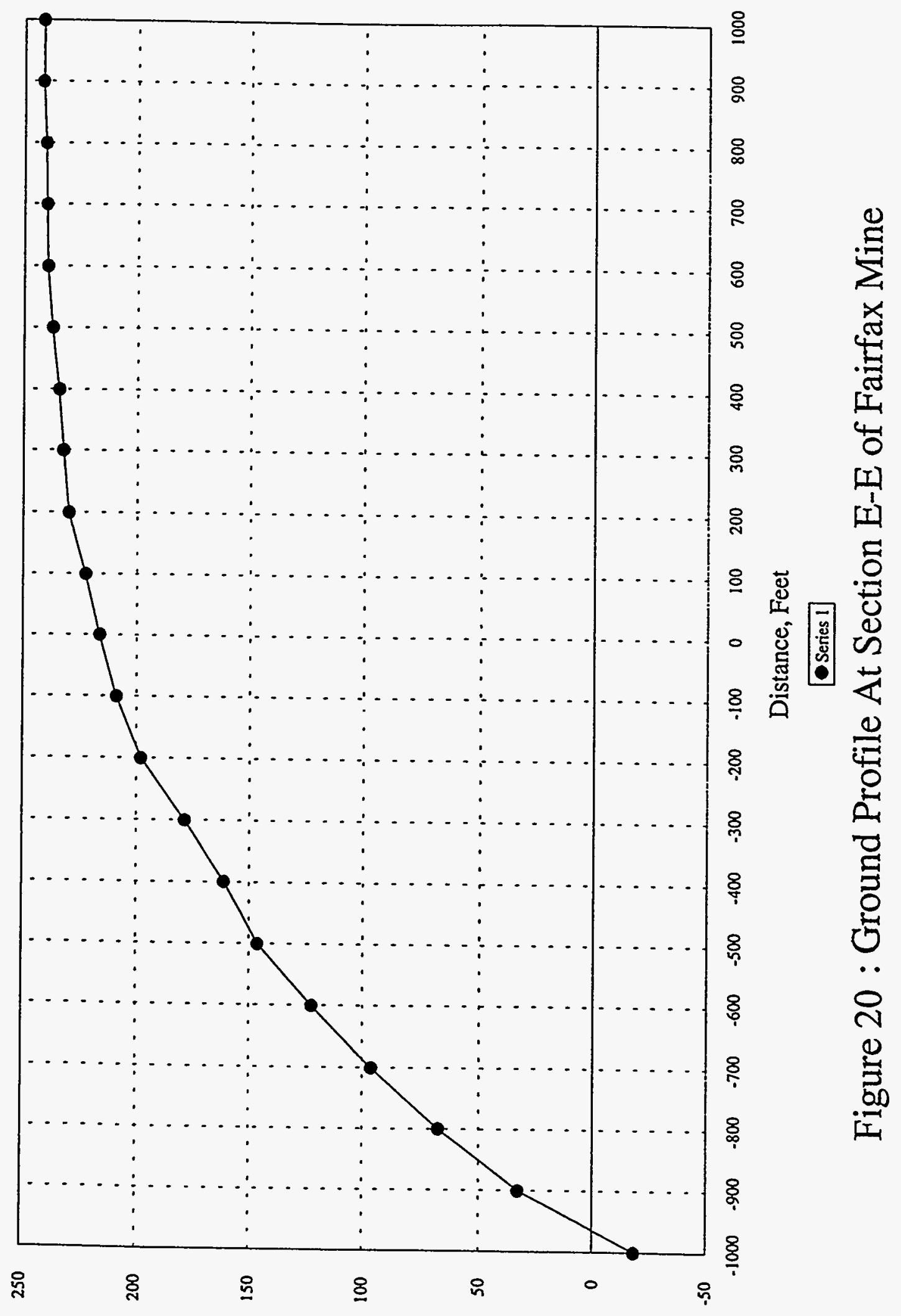

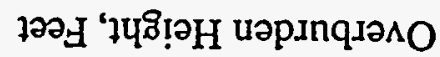




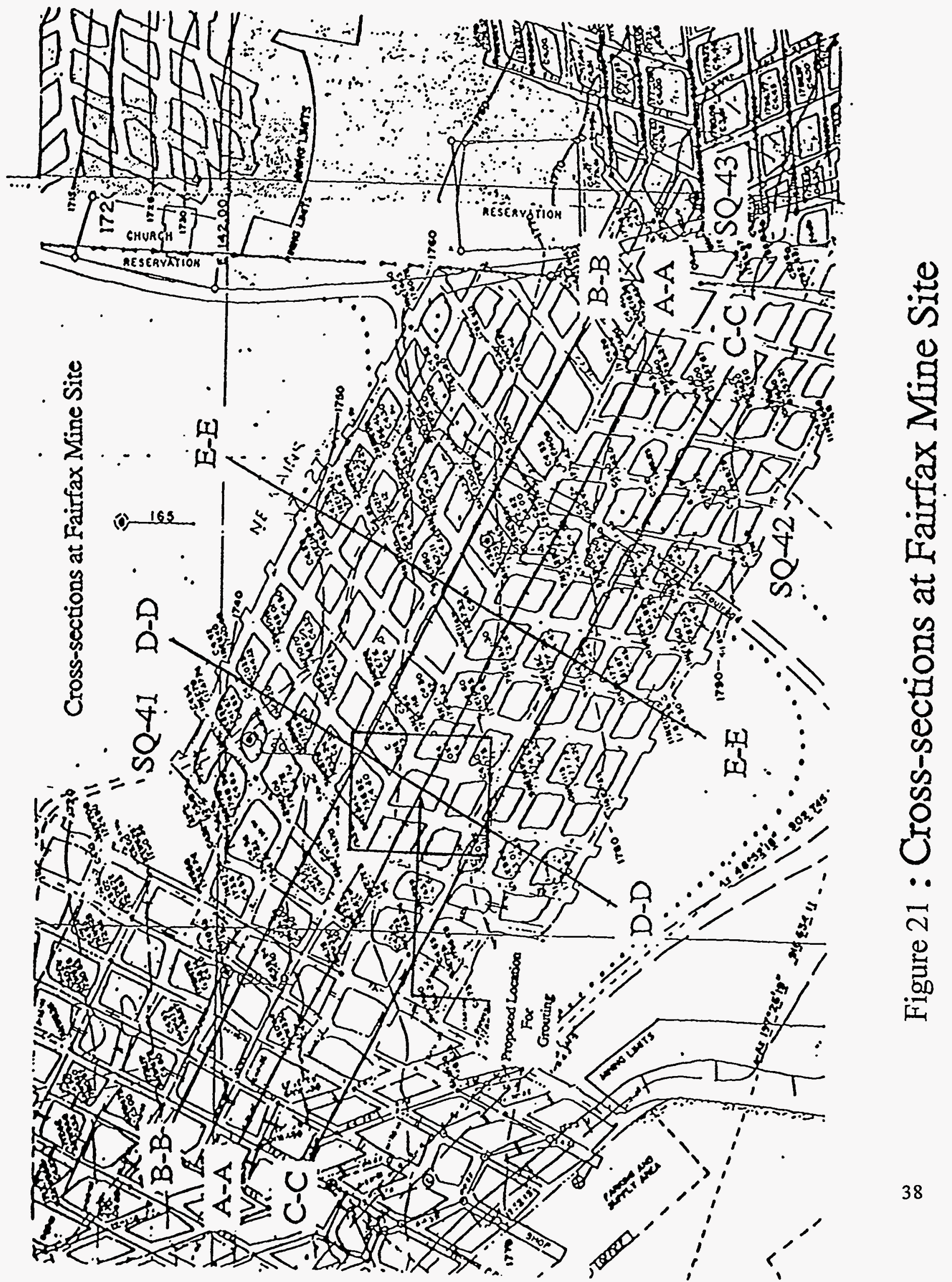




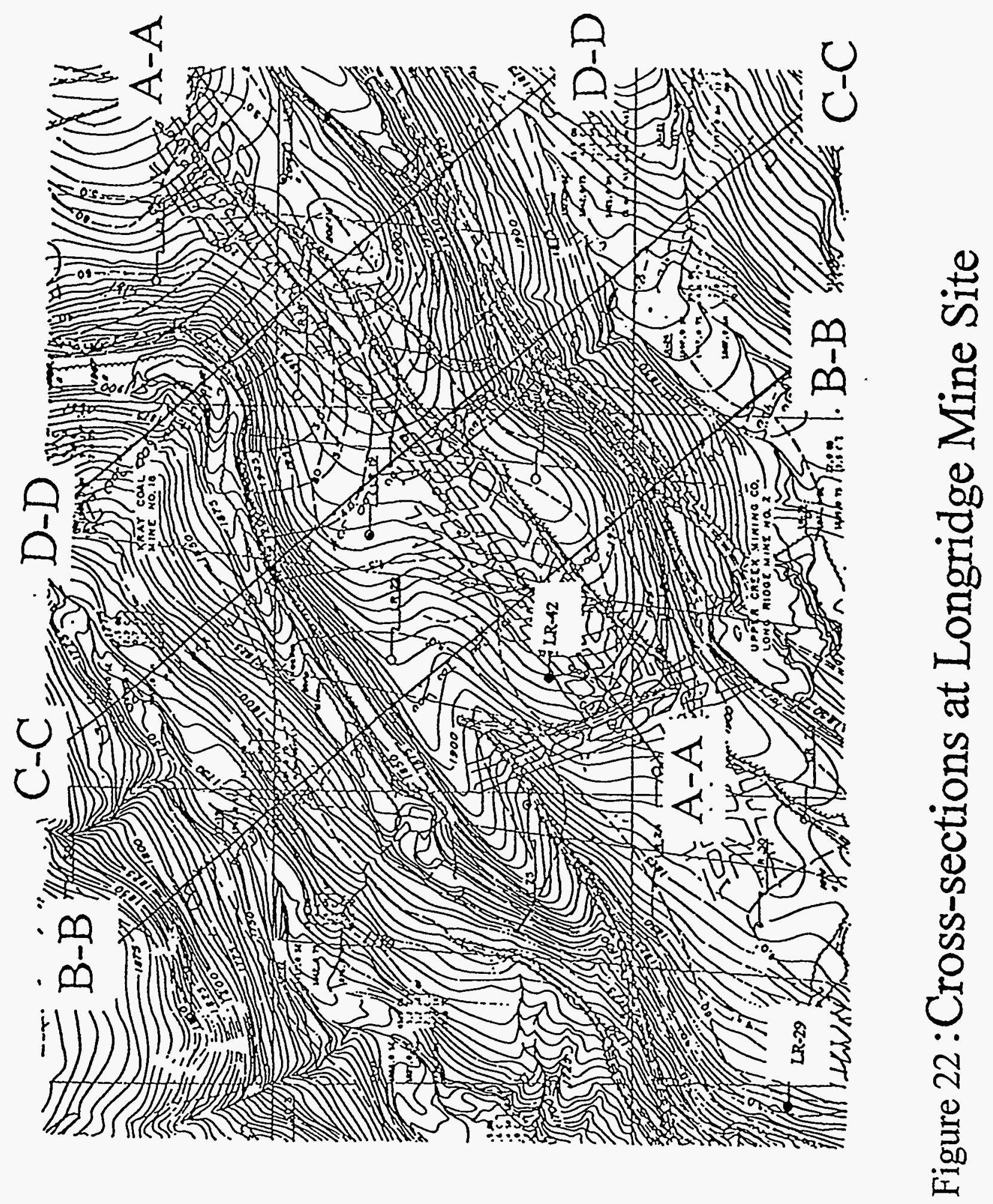




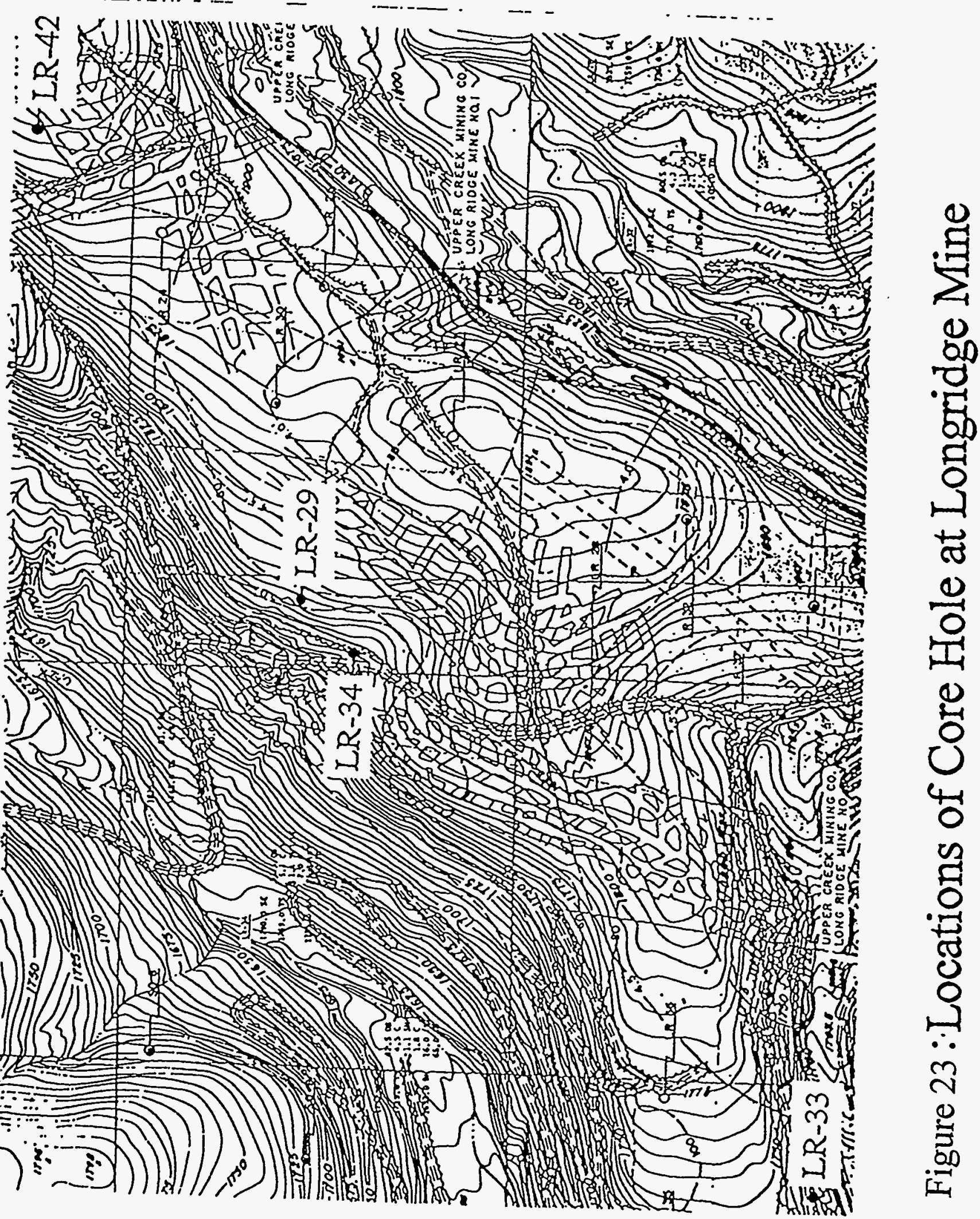




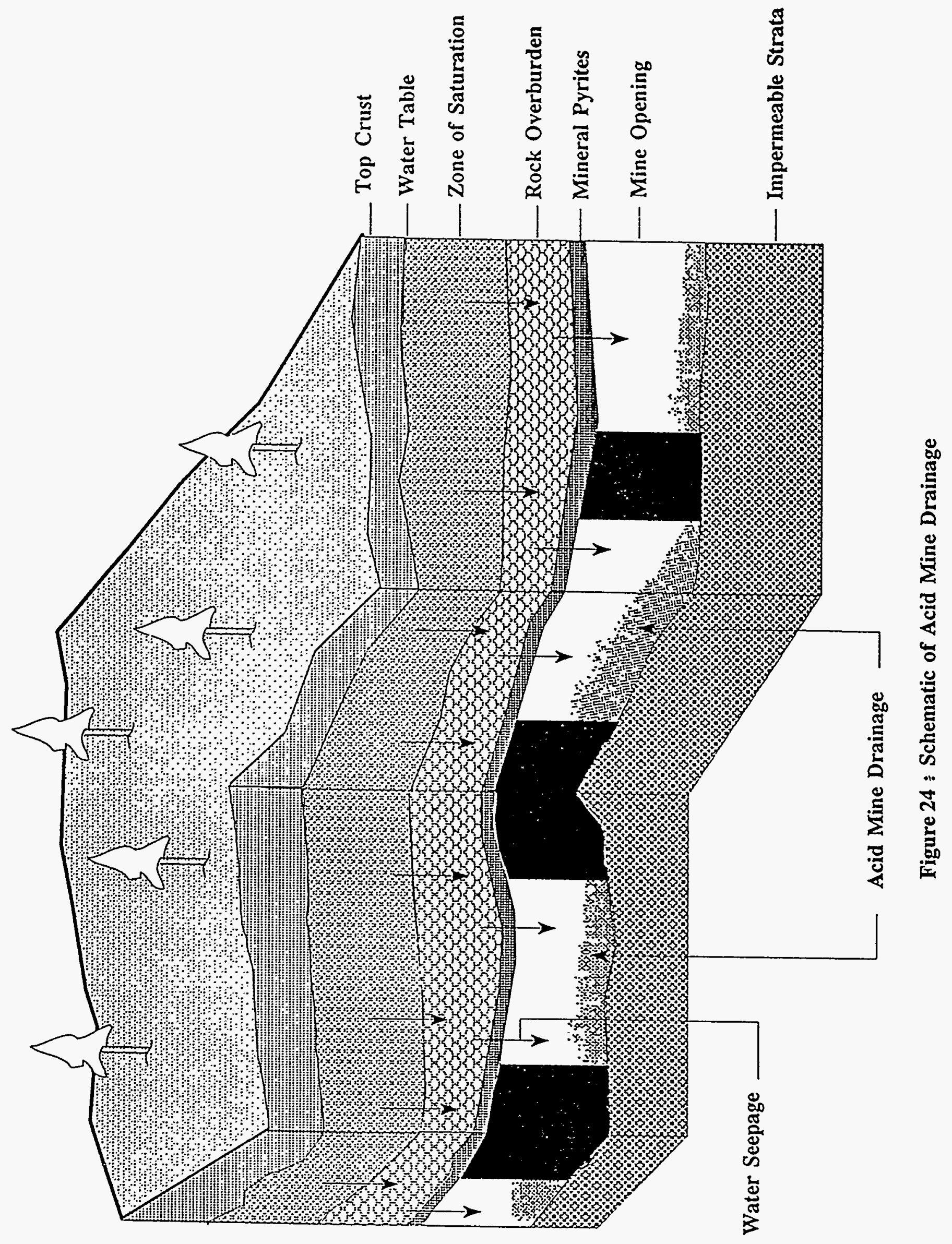


Table 3: Overburden Height At Section D-D Of Fairfax Mine

\begin{tabular}{|c|c|c|c|c|}
\hline Coordinates & $\begin{array}{l}\text { Ground } \\
\text { Elevation }\end{array}$ & $\begin{array}{l}\text { Coal } \\
\text { Elevation }\end{array}$ & $\begin{array}{l}\text { Overburden } \\
\text { Height } \\
\text { ( z ) }\end{array}$ & $\begin{array}{l}\text { Adjusted } \\
\text { Overburden } \\
\text { Height } \\
\left(z_{c}\right) \\
\end{array}$ \\
\hline-1000 & 1820 & 1829.5 & -9.5 & 5.5 \\
\hline-900 & 1840 & 1823 & 17 & 32 \\
\hline-800 & 1860 & 1816 & 44 & 59 \\
\hline-700 & 1880 & 1806 & 74 & 89 \\
\hline-600 & 1900 & 1802.5 & 97.5 & 112.5 \\
\hline-500 & 1920 & 1795.5 & 124.5 & 139.5 \\
\hline-400 & 1940 & 1788.5 & 151.5 & 166.5 \\
\hline-300 & 1940 & 1782.3 & 162.9 & 177.6 \\
\hline-200 & 1940 & 1776 & 166.7 & 181.7 \\
\hline-100 & 1940 & 1769.1 & 170.9 & 185.9 \\
\hline 0 & 1953.3 & 1762.5 & 190.8 & 205.8 \\
\hline 100 & 1962.2 & 1755.4 & 206.8 & 221.8 \\
\hline 200 & 1968.1 & 1748.8 & 219.3 & 234.3 \\
\hline 300 & 1974 & 1742.3 & 231.7 & 246.7 \\
\hline 400 & 1980 & 1736 & 244 & 259 \\
\hline 500 & 1966.6 & 1728 & 238.6 & 253.6 \\
\hline 600 & 1956 & 1722 & 234 & 249 \\
\hline 700 & 1948 & 1715 & 233 & 248 \\
\hline 800 & 1943.5 & 1708 & 235.5 & 250.5 \\
\hline 900 & 1940.5 & 1703 & 237.5 & 252.5 \\
\hline 1000 & 1937.8 & 1697.5 & 240.3 & 255.3 \\
\hline
\end{tabular}

Note; $\mathrm{Zc}=\mathrm{z}+15$ Feet*

$* 5$ Feet Coal +10 Feet Underburden 
Table 4: Overburden Height At Section E-E Of Fairfax Mine

\begin{tabular}{|c|c|c|c|c|}
\hline Coordinates & $\begin{array}{l}\text { Ground } \\
\text { Elevation }\end{array}$ & $\begin{array}{l}\text { Coal } \\
\text { Elevation }\end{array}$ & $\begin{array}{l}\text { Overburden } \\
\text { Height } \\
\text { (z) }\end{array}$ & $\begin{array}{l}\text { Adjusted } \\
\text { Overburden } \\
\text { Height } \\
\left(z_{c}\right) \\
\end{array}$ \\
\hline-1000 & 1815 & 1848.5 & -33.5 & -18.5 \\
\hline-900 & 1860 & 1842 & 18 & 33 \\
\hline-800 & 1887.5 & 1835 & 52.5 & 67.5 \\
\hline-700 & 1909 & 1827.8 & 81.2 & 96.2 \\
\hline-600 & 1928 & 1820.5 & 107.5 & 122.5 \\
\hline-500 & 1944.4 & 1813.2 & 131.2 & 146.2 \\
\hline-400 & 1953.3 & 1806.8 & 146.5 & 161.5 \\
\hline-300 & 1963 & 1799 & 164 & 179 \\
\hline-200 & 1975.4 & 1792.5 & 182.9 & 197.9 \\
\hline-100 & 1980 & 1786 & 194 & 209 \\
\hline 0 & 1980 & 1778.5 & 201.5 & 216.5 \\
\hline 100 & 1980 & 1772.3 & 207.7 & 222.7 \\
\hline 200 & 1980 & 1765 & 215 & 230 \\
\hline 300 & 1975.15 & 1757.8 & 217.4 & 232.4 \\
\hline 400 & 1970.3 & 1750.5 & 219.4 & 234.4 \\
\hline 500 & 1965.4 & 1743 & 222.4 & 237.4 \\
\hline 600 & 1960.6 & 1736 & 224.6 & 239.6 \\
\hline 700 & 1954.1 & 1729 & 225.1 & 240.1 \\
\hline 800 & 1947.5 & 1722 & 225.5 & 240.5 \\
\hline 900 & 1940.8 & 1714 & 226.8 & 241.8 \\
\hline 1000 & 1933.5 & 1707 & 226.5 & 241.5 \\
\hline
\end{tabular}

Note; $\mathrm{Zc}=\mathrm{z}+15$ Feet*

*5 Feet Coal +10 Feet Underburden 
Table 5: Material Properties Used For The Analysis Of Fairfax Mine

\begin{tabular}{|l|l|l|l|l|l|l|l|}
\hline $\begin{array}{l}\text { Rock } \\
\text { Type }\end{array}$ & $\begin{array}{l}\text { Elastic } \\
\text { Modulus } \\
\times 10^{6} \mathrm{psi}\end{array}$ & $\begin{array}{l}\text { Poisson's } \\
\text { Ratio }\end{array}$ & $\begin{array}{l}\text { Unit } \\
\text { Weight pcf }\end{array}$ & $\begin{array}{l}\text { Cohesion } \\
\mathrm{c} \mathrm{psi}\end{array}$ & $\begin{array}{l}\text { Internal } \\
\text { Friction } \\
\Phi \text { deg }\end{array}$ & $\begin{array}{l}\text { Tensile } \\
\text { Strength } \\
\mathrm{psi}\end{array}$ & $\begin{array}{l}\text { Coef. of } \\
\text { e-pressure } \\
\text { at rest } \\
k_{0}\end{array}$ \\
\hline Soil & 0.007 & 0.30 & 120.0 & 2.0 & 20.0 & 2.0 & 0.50 \\
\hline Shale & 0.960 & 0.15 & 160.0 & 2904.0 & 33.0 & 650.0 & 0.51 \\
\hline $\begin{array}{l}\text { Sandy } \\
\text { Shale }\end{array}$ & 2.81 & 0.257 & 160.0 & 4260.0 & 31.4 & 15184.0 & 0.48 \\
\hline Sandstone & 5.6 & 0.15 & 160.0 & 2336.0 & 28.0 & 851.0 & 0.46 \\
\hline Coal & 0.180 & 0.30 & 83.0 & 1000.0 & 30.0 & 207.0 & 0.48 \\
\hline
\end{tabular}


Table 6: Material Properties Used For The Analysis Of Longridge Mine

\begin{tabular}{|l|l|l|l|l|l|l|l|}
\hline $\begin{array}{l}\text { Rock } \\
\text { Type }\end{array}$ & $\begin{array}{l}\text { Elastic } \\
\text { Modulus } \\
\times 10^{6} \mathrm{psi}\end{array}$ & $\begin{array}{l}\text { Poisson's } \\
\text { Ratio }\end{array}$ & $\begin{array}{l}\text { Unit } \\
\text { Weight pcf }\end{array}$ & $\begin{array}{l}\text { Cohesion } \\
\mathrm{cpsi}\end{array}$ & $\begin{array}{l}\text { Internal } \\
\text { Friction } \\
\Phi \text { deg }\end{array}$ & $\begin{array}{l}\text { Tensile } \\
\text { Strength } \\
\text { psi }\end{array}$ & $\begin{array}{l}\text { Coef. of } \\
\text { e-pressure } \\
\text { at rest } \\
\mathrm{k}_{\mathrm{o}}\end{array}$ \\
\hline Soil & 0.007 & 0.30 & 120.0 & 2.0 & 20 & 2 & 0.50 \\
\hline Shale & 0.960 & 0.15 & 160.0 & 2904.0 & 33 & 650 & 0.51 \\
\hline $\begin{array}{l}\text { Sandy } \\
\text { Shale }\end{array}$ & 2.81 & .257 & 160 & 4260 & 31.4 & 15184 & .48 \\
\hline Sandstone & 5.6 & 0.15 & 160.0 & 2336.0 & 28 & 851 & 0.46 \\
\hline Coal & 0.180 & 0.30 & 83.0 & 1000.0 & 30 & 207 & 0.48 \\
\hline
\end{tabular}


Table 7: Stress At The Level Of Coal Seam Due To Overburden At Fairfax Mine Site

\begin{tabular}{|c|c|c|}
\hline Core Holes & Stress In psf & Stress In psi \\
\hline SQ-41 & 34495 & 239.54 \\
\hline SQ-42 & 35035 & 243.29 \\
\hline SQ-43 & 32815 & 227.88 \\
\hline
\end{tabular}


Table 8: Stress At The Level Of Coal Seam Due To Overburden At Longridge Mine Site

\begin{tabular}{|c|c|c|}
\hline Core Holes & Stress In psf & Stress In psi \\
\hline LR-29 & 8982.5 & 62.37 \\
\hline LR-33 & 10488.5 & 72.83 \\
\hline LR-34 & 5456.25 & 38.51 \\
\hline LR-42 & 14905.5 & 103.51 \\
\hline
\end{tabular}

